\title{
Revision of the Malagasy lanternfly genus Belbina Stål, 1863, with two new species (Hemiptera: Fulgoromorpha: Fulgoridae)
}

\author{
Jérôme CONSTANT \\ Royal Belgian Institute of Natural Sciences, O.D. Phylogeny and Taxonomy, Entomology, \\ Vautier Street 29, B-1000 Brussels, Belgium. E-mail: jerome.constant@naturalsciences.be \\ urn:lsid:zoobank.org:author:6E6072A1-9415-4C8D-8E60-2504444DB290
}

\begin{abstract}
The Malagasy genus Belbina Stål, 1863 (Hemiptera: Fulgoridae) is revised, transferred from the Enchophorinae Haupt, 1829 to the Aphaeninae Blanchard, 1847, and two new species, B. bourgoini sp. nov. and B. laetitiae sp. nov., are described. The genus Cornelia Stål, 1866 is proposed as a junior synonym of Belbina. The following new combinations are proposed: Belbina bergrothi (Schmidt, 1911) comb. nov. and B. nympha (Stål, 1866) comb. nov. The combination Belbina foliacea Lallemand, 1950 is restored. Aphana madagascariensis Westwood, 1851 is redescribed, transferred to Belbina and the new combination B. madagascariensis (Westwood, 1851) is proposed. Belbina vicina Lallemand, 1959 is proposed as a junior synonym of B. falleni Stål, 1863 and Cornelia atomaria (Brancsik, 1893) as a junior synonym of Belbina nympha (Stål, 1866). Neotypes are designated for B. madagascariensis (Westwood, 1851) comb. nov. and B. servillei (Spinola, 1839). The genus now comprises 12 species from Madagascar. A list of diagnostic characters, an identification key, illustrations of the male genitalia and distribution maps are provided. The falleni+ species group is defined based on characters of the male genitalia and contains the following 5 species: B. bloetei Lallemand, 1959, B. falleni Stål, 1863, B. laetitiae sp. nov., B. lambertoni Lallemand, 1922 and B. pionneaui Lallemand, 1922.
\end{abstract}

Keywords. Madagascar, lanternbug, Fulgoroidea, Homoptera, planthopper

Constant J. 2014. Revision of the Malagasy lanternfly genus Belbina Stål, 1863, with two new species (Hemiptera: Fulgoromorpha: Fulgoridae). European Journal of Taxonomy 102: 1-37. http://dx.doi.org/10.5852.ejt.2014.102

\section{Introduction}

In the process of identifying material of Fulgoridae from Madagascar, three species attributed to the genera Belbina Stål, 1863 or Cornelia Stål, 1866 were found that were not listed in the works of Lallemand (1959) or Constant (2004b). Two appear to be undescribed, while the third one represents the enigmatic Aphana madagascariensis Westwood, 1851.

The genus Belbina was described by Stål (1863a) to accommodate two species: Belbina falleni Stål, 1863 (Madagascar) and Enchophora servillei Spinola, 1839 (patria incognita, now recognized to be Madagascar). It was redescribed by Stål (1863b) later the same year, leading to misinterpretation by Metcalf (1947) who erroneously designated Enchophora sicca Walker, 1851 (South Africa) as the type species of Belbina. Lallemand (1959) validly designated Belbina falleni Stål, 1863 as the type species, 
a view followed by Nast (1977) who clarified this issue according to the dates of publication of Stål's papers.

Stål (1866) later described Cornelia for C. nympha Stål, 1866, from Madagascar.

Gerstaecker (1873) described the genus Pyrgoteles for Enchophora sicca Walker, 1851 and considered the genus close to Belbina Stål, 1863, and to the Oriental genera Aphaena Guérin-Méneville, 1834 and Prolepta Walker, 1851.

Karsch (1890) synonymized Pyrgoteles under Belbina. Nevertheless, in 1893 the same author described a new species in the genus Pyrgoteles, P. cristatus Karsch, 1893, thus de facto revalidating the genus Pyrgoteles.

Melichar (1908) added one species from Africa (Tanzania) to Cornelia: C. usambarae.

Schmidt (1911) described another species in Cornelia, C. bergrothi from Madagascar and placed Cornelia in the Aphaenini of the Fulgorinae (note that the concept of the Fulgorinae at that time equals present Fulgoridae and Aphaenini equals present Aphaeninae).

In 1918, Schumacher reviewed Druentia Stål, 1866 and considered Pyrgoteles Gerstaecker, 1873 and Belbina Stål, 1863 as junior synonyms of Druentia, the latter synonymy being invalid since Belbina has priority over Druentia. Lallemand (1922) restored Belbina by adding two new species from Madagascar, B. lambertoni (with a variety, minuta) and B. pionneaui.

In his catalogue of the Fulgoridae, Metcalf (1947) listed 3 species in Cornelia and 4 in Belbina (and one variety). He included the species sicca Walker, 1951 in Druentia Stål, 1866 although he also strangely considered it the type species of Belbina Stål, 1863, even placing the two genera in different subfamilies: Druentia in the Amyclinae, Amyclini and Belbina in the Aphaeninae, Enchophorini.

In 1950, Lallemand added 2 species in Belbina: B. recurva and B. foliacea from Madagascar.

In his revision of the Afrotropical Fulgoridae, Lallemand (1959) considered Druentia as strictly African and Cornelia and Belbina as restricted to Madagascar. He placed the 3 genera in the subfamily Enchophorinae Haupt, 1829, which appears to be exclusively Neotropical, with Enchophora Spinola, 1839 as the type genus (type species, E. recurva (Olivier, 1891), described from Surinam; see also phylogenetic trees based on molecular data in Urban \& Cryan 2009). He considered Enchophorinae a subfamily instead of following Metcalf(1947), who considered it a tribe within the Aphaeninae Blanchard, 1847. He gave a key to separate the genera based on characters such as the width of the head and the shape of the tegmina and cephalic process. He transferred Belbina foliacea and Enchophora atomaria Brancsik, 1893 to Cornelia, described Belbina bloetei and B. vicina (the 4 species from Madagascar), and transferred Cornelia usambarae Melichar, 1908 (from Tanzania) to Druentia. He synonymized Belbina lambertoni var. minuta Lallemand, 1922 under B. lambertoni Lallemand, 1922. Finally, he erroneously designated a specimen in his collection as lectotype for Belbina servillei (Spinola, 1839), a specimen that is not from the type series and not even the right species.

Constant (2004b) gave a key to the genera of Fulgoridae found in Madagascar (mainly based on Lallemand 1959) and a checklist of the Fulgoridae of Madagascar, including 7 species in Belbina and 4 species in Cornelia, and stated that Cornelia and Druentia could be junior synonyms of Belbina. He also mentioned the invalid designation by Lallemand (1959) of a lectotype for Belbina servillei. 
This paper aims to clarify the taxonomy of the genus and the specific concept of several taxa based on illustrated morphological characters, with the description of two new species.

The current concepts of all the taxa mentioned are documented in FLOW (Bourgoin 2014).

\section{Materials and methods}

The type specimens of all species have been examined. The male genitalia were dissected as follows: the pygofer was cut from the abdomen of the softened specimen with a needle blade. It was then boiled in water for a few minutes for cleaning and to facilitate removal of pieces of tegument from the last abdominal segments. It was then dried and placed under the specimen in a gelatin capsule after examination. Endosomal characters were not used due to the difficulty to correctly inflate the membranous endosome and because it is not indispensible to separate the species in the genus Belbina. Observations were done with a Leica MZ8 stereo microscope. Pictures of specimens were taken with a Canon EOS 300 D camera with a Sigma DG Macro lens and optimized with Photoshop CS3. Pictures of genitalia were taken with a Leica DFC290 camera mounted on a Leica Z6 APO microscope, using LAS V4 software for image capture. Each series of pictures was processed with Combine ZP and optimized with Adobe Photoshop CS5.

The disc designates the central area of the tegmen, roughly covering the zone between the subcostal vein, claval joint and nodal line.

For the transcription of the labels of the types, the exact wording on each label is provided within square brackets. In the results section, species are treated in alphabetical order.

Acronyms used for the collections (name of the curator in parentheses) are as follows:

BMNH $=$ The Natural History Museum, London, United Kingdom (M. Webb)

CAS $=$ California Academy of Sciences, San Francisco, USA (Norman D. Penny)

FSAG = Faculté des Sciences agronomiques de Gembloux, Gembloux, Belgium (Eric Haubruge, Jeannine Bortels)

HNHM $=$ Hungarian Natural History Museum, Budapest, Hungary (Andras Orosz)

INHS $=$ Illinois Natural History Survey, Champaign, USA (Chris Dietrich)

MHNL $=$ Muséum d'Histoire Naturelle de Lyon, France (Cédric Audibert)

MNHN = Muséum National d'Histoire Naturelle, Paris, France (Thierry Bourgoin, Adeline Soulier-Perkins)

MRAC = Musée royal de l'Afrique centrale, Tervuren, Belgium (Marc De Meyer, Ugo Dall'Asta)

NCSU $=$ North Carolina State University, Raleigh, USA (Bob Blinn)

NHRS $=$ Naturhistoriska Riksmuseet, Stockholm, Sweden (Gunvi Lindberg)

NMPC = National Museum, Praha, Czech Republic (Petr Kment)

NMW $=$ Naturhistorisches Museum Wien, Vienna, Austria (Herbert Zettel)

RBINS $=$ Royal Belgian Institute of Natural Sciences, Brussels, Belgium (Wouter Dekoninck)

RMNH = Nationaal Natuurhistorisch Museum ("Naturalis"), Leiden, Netherlands (Jan van Tol, Yvonne van Nierop)

SDEI = Senckenberg Deutsches Entomologisches Institut, Müncheberg, Germany (Stephan Blank)

ZIN = Russian Academy of Sciences, Zoological Institute, St. Petersburg, Russia (Vladimir Gnezdilov) 


\section{Results}

Class Hexapoda Blainville, 1816

Order Hemiptera Linnaeus, 1758

Suborder Auchenorrhyncha Duméril, 1806

Infraorder Fulgoromorpha Evans, 1946

Superfamily Fulgoroidea Latreille, 1807

Family Fulgoridae Latreille, 1807

Subfamily Aphaeninae Blanchard, 1847

Morphological characters (shape of pro- and mesonotum, carinae of head, tegmina and wing venation) and especially recent molecular data (Urban \& Cryan 2009) lead to the conclusion that Belbina should be transferred to Aphaeninae. The genus is close to the African genera Anecphora Karsch, 1890 and Rhicnophloea Gerstaecker, 1895 (the latter mentioned as 'undet. Fulgoridae' in Urban \& Cryan 2009: fig. 3) and to the Oriental genera Penthicodes Blanchard, 1845 and Kalidasa Kirkaldy, 1900. The colour pattern in Belbina is very similar to that found in Penthicodes, species of Belbina looking somewhat like "Penthicodes with erected cephalic process" (see also Constant 2010 for illustrations of species of Penthicodes).

Belbina Stål, 1863

Belbina Stål, 1863a: 232. Type species: Belbina falleni Stål, 1863 by subsequent designation by Lallemand (1959).

Cornelia Stål, 1866: 133 (key), 142. syn. nov. Type species: Cornelia nympha Stål, 1866, by monotypy.

Belbina - Stål 1863b: 580 (redescription). — Stål 1866: 134 (key), 143 (description, key to species). Karsch 1890: 61 (listed; erroneous synonymy with Pyrgoteles Gertsaecker, 1873). — Jacobi 1917: 520 (listed). - Lallemand 1922: 62 (listed, description of new species). — Metcalf 1947: 123 (catalogued). — Lallemand 1950: 84 (description of new species). — Lallemand 1959: 85 (key), 88 (description, key to species). - Nast 1977: 30 (nomenclature). - Constant 2004b: 31 (key, list of species).

Cornelia - Karsch 1890: 61 (listed). — Schmidt 1911: 241 (listed, description of new species). — Jacobi 1917: 520 (listed). — Metcalf 1947: 122 (catalogued). — Lallemand 1959: 85 (key), 86 (description, key to species). - Constant 2004b: 31 (key, list of species).

Druentia - Schumacher 1918: 111 pars (erroneous synonymy).

\section{Remarks}

Belbina and Cornelia are synonymized because it is not possible to find any characters allowing consistent separation of these taxa. When all species of both genera are taken into account, a gradient can be observed from the larger species (e.g., falleni and recurva) to the smaller ones (e.g., nympha and bergrothi) in all characters supposed to separate the genera, i.e., (1) the width of the vertex (supposedly narrower than eye in Cornelia and broader than eye in Belbina), (2) vertex prolonged directly on cephalic process (Cornelia) or not (Belbina) and (3) hind margin of tegmina cut transversely (Cornelia) or rounded (Belbina).

The close relationship and possible synonymy of Belbina and Druentia mentioned by Constant (2004) is not supported by the results of recent molecular studies. According to a preliminary analysis (Julie Urban pers. comm., Nov. 2013), Druentia is sister to Rhicnophloea Gerstaecker, 1895 and [Druentia + Rhicnophloea] is sister to a larger clade of Old World taxa which contains, among others, a group 
formed by [Samsama Distant, 1906 + Belbina + Metaphaena Schmidt, 1905 + Anecphora + Penthicodes] (Urban, Bartlett \& Cryan unpubl. data).

Five of the twelve currently known species of Belbina seem very close and share very similar male genitalia with the following common characters: (1) pygofer, anal tube and gonostyli red or dark red; (2) gonostyli elongate with ventral margin concave in lateral view and roundly pointed apically; (3) gonostyli with strong basodorsal digitiform process directed dorsolaterally or dorsoposteriorly; (4) anal tube broadening more or less regularly from base to apex. This group is defined as the fallen $i^{+}$group and contains B. bloetei, B. falleni, B. laetitiae sp. nov., B. lambertoni and B. pionneaui.

\section{Diagnostic characters}

The genus can be recognized by the following combination of characters: (1) head much narrower than pronotum; (2) frons longer than broad, with longitudinal carinae; (3) cephalic process present, about as long as frons and projecting anterodorsally to posterodorsally; (4) lateral carinae of cephalic process (i.e., prolongation of the lateral carinae of frons and of vertex) fused in a single longitudinal carina before apex of process; (5) pronotum with a strong tectiform median carina and a deeply impressed point on each side of it.

Belbina is very similar to Druentia but can be separated by character (4): in Druentia the lateral carinae of the vertex reach the apex of the cephalic process without fusing together.

\section{Sexual dimorphism}

Males 15 to $30 \%$ smaller in size than females.

\section{Distribution}

Only recorded from Madagascar.

\section{Identification key to the species of Belbina}

The disc of the hind wings can be either orange or red in some species (observed in B. bergrothi, $B$. madagascariensis and $B$. nympha). It is possible that other species presently known only from red hindwinged specimens also have ones with orange hind wings.

The red colour of the abdomen can also fade to orange or yellow in collection specimens, especially if they have been preserved in ethanol.

1. Hind wings red or orange on disc (Figs 1A, 2A) 2

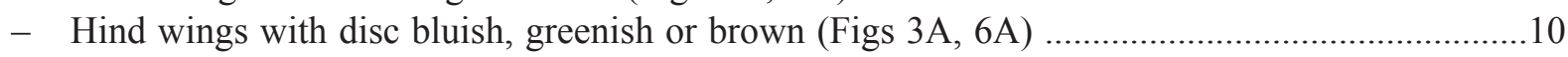

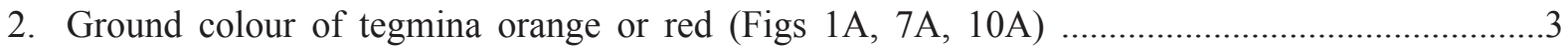

- Ground colour of tegmina brown to pale rosy brown (Figs 2A, 4A) ......................................

3. Mesonotum with 2 black patches on disc (Fig. 1C); small-sized (less than $22 \mathrm{~mm}$ long)

- Mesonotum without black patches (Figs 7C, 10C); larger (more than $24 \mathrm{~mm}$ long) ..............4

4. Tegmina orange to red with minute black spots; 3 large black patches on costal cell and one at the base of clavus (Fig. 7A)

Belbina lambertoni Lallemand, 1922 
- Tegmina dark red with membrane pale brown; numerous, irregular, blackish brown spots (Fig. 10A)

Belbina pionneaui Lallemand, 1922

5. Head with a foliaceous process above the eye, higher than diameter of eye in side view; median carina of pronotum strongly sinuate and elevated posteriorly in side view (Fig. 5D) .....

Belbina foliacea Lallemand, 1959

- Head without large foliaceous process above the eye, process reduced to a lamina not higher than half of diameter of eye; median carina of pronotum not strongly sinuate and elevated posteriorly in side view (Figs 4D, 11D)

6. Small-sized, less than $22 \mathrm{~mm}$ long; cephalic process directed anterodorsad (Fig. 9D); abdomen with 2 dorsal rows of black spots; hind wings with 4-6 little black spots on red zone (Fig. 9A)

Belbina nympha (Stål, 1866)

- Larger, more than $26 \mathrm{~mm}$ long; cephalic process angulously directed dorsad or posteriorad (Fig. 2D), or, if not, dorsum of abdomen red without rows of black spots; hind wings with 2 small black spots or larger black spots (Figs 4A, 8A)

7. Cephalic process narrow, elongate, obliquely directed anterodorsad (Fig. 8D); blackish brown spots with pale center on tegmina (Fig. 8A) ............Belbina madagascariensis (Westwood, 1851)

- Cephalic process broad, strongly curved dorsad or posteriorad (Fig. 2D); dark spots on tegmina

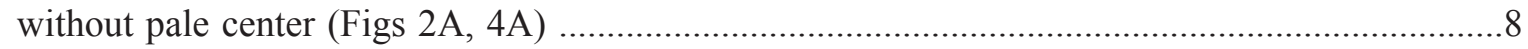

8. Cephalic process projecting dorsad, apex not surpassing level of anterior margin of eye in lateral view (Fig. 2D); abdomen without rows of black spots dorsally; no large black patch on basal half of claval joint; no paler transverse patch at half length of tegmen (Figs 2A, 4A) ...9

- Cephalic process more strongly curved and projecting posterodorsad, reaching level of posterior margin of eye in lateral view (Fig. 11D); abdomen with 2 rows of blackish spots dorsally; one large black elongate patch on basal half of claval joint; one transverse paler patch at about half of length of tegmen (Fig. 11A) Belbina recurva Lallemand, 1950

9. Ground colour of tegmina and head pale rosy brown; a rectangular paler patch on clavus (Fig. 2A) Belbina bloetei Lallemand, 1959

- Ground colour of tegmina and head brown; no evident paler patch on clavus (Fig. 4A)

Belbina falleni Stål, 1863

10. Head, pro- and mesonotum red (Fig. 12C-E); ground colour of tegmina bluish green (Fig. 12A) Belbina servillei (Spinola, 1839)

- Head, pro- and mesonotum brown (Figs 3C-D; 6C-D); ground colour of tegmina bluish green or brownish (Figs 3A, 6A) ...11

11. Ground colour of tegmina bluish green; hind wings nearly totally infuscate with a suturobasal, not well limited zone, and spots, paler, milky (Fig. 6A); larger (24 mm long in males, $27 \mathrm{~mm}$ long in females) Belbina laetitiae sp. nov.

- Ground colour of tegmina brownish with a dark reddish band after half of length; hind wings with paler, bluish green disc very distinctly separated from blackish apex and sutural margin (Fig. 3A); smaller (19 mm long in males)

Belbina bourgoini sp. nov. 

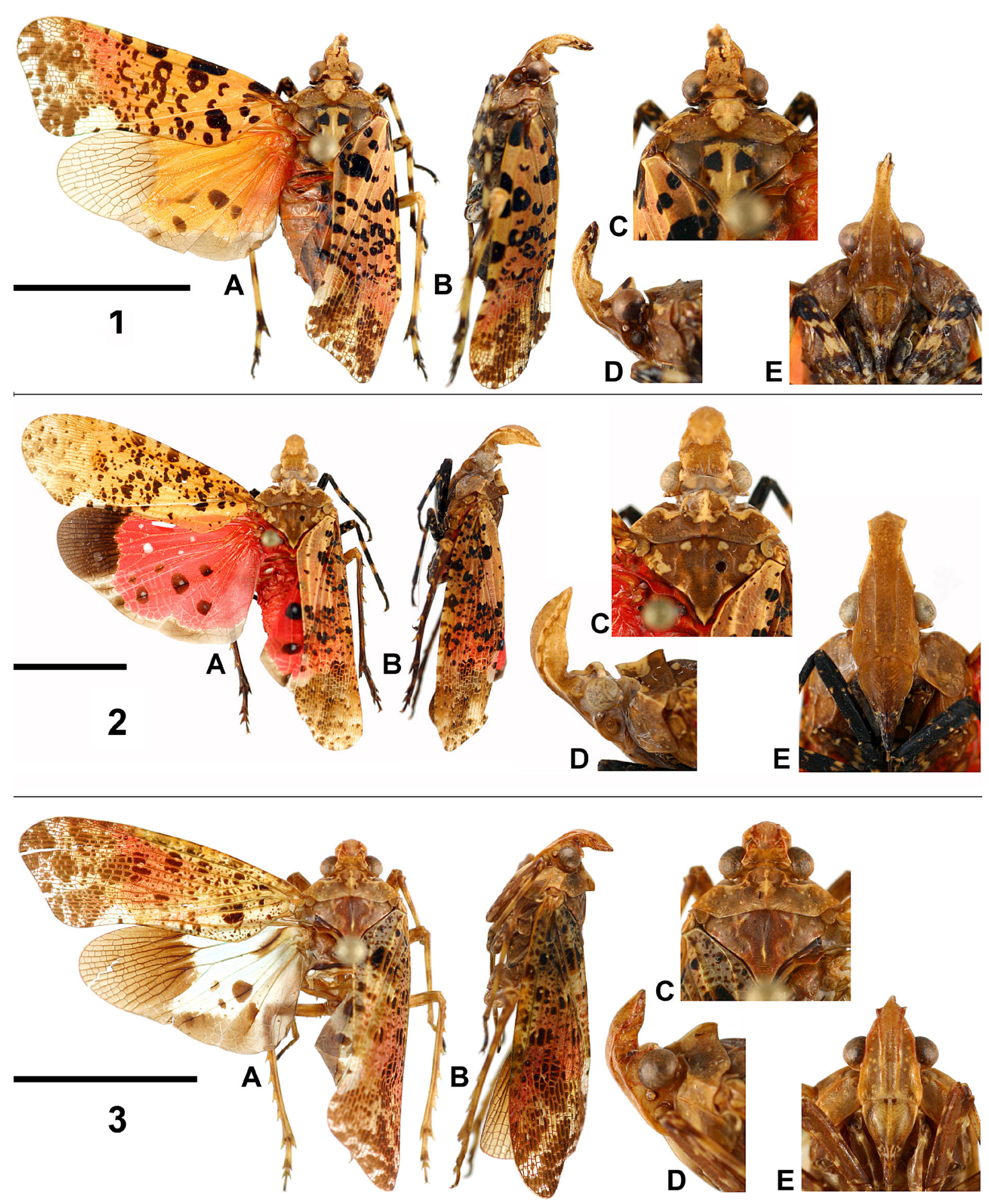

Figs 1-3. - 1. Belbina bergrothi. 2. B. bloetei. 3. B. bourgoini sp. nov. - A. Habitus, dorsal view. B. Habitus, lateral view. C. Vertex, pro- and mesonotum, dorsal view. D. Head and prothorax, lateral view. E. Frons, normal view. - Scale bar: $10 \mathrm{~mm}$ (C-E not to scale). 

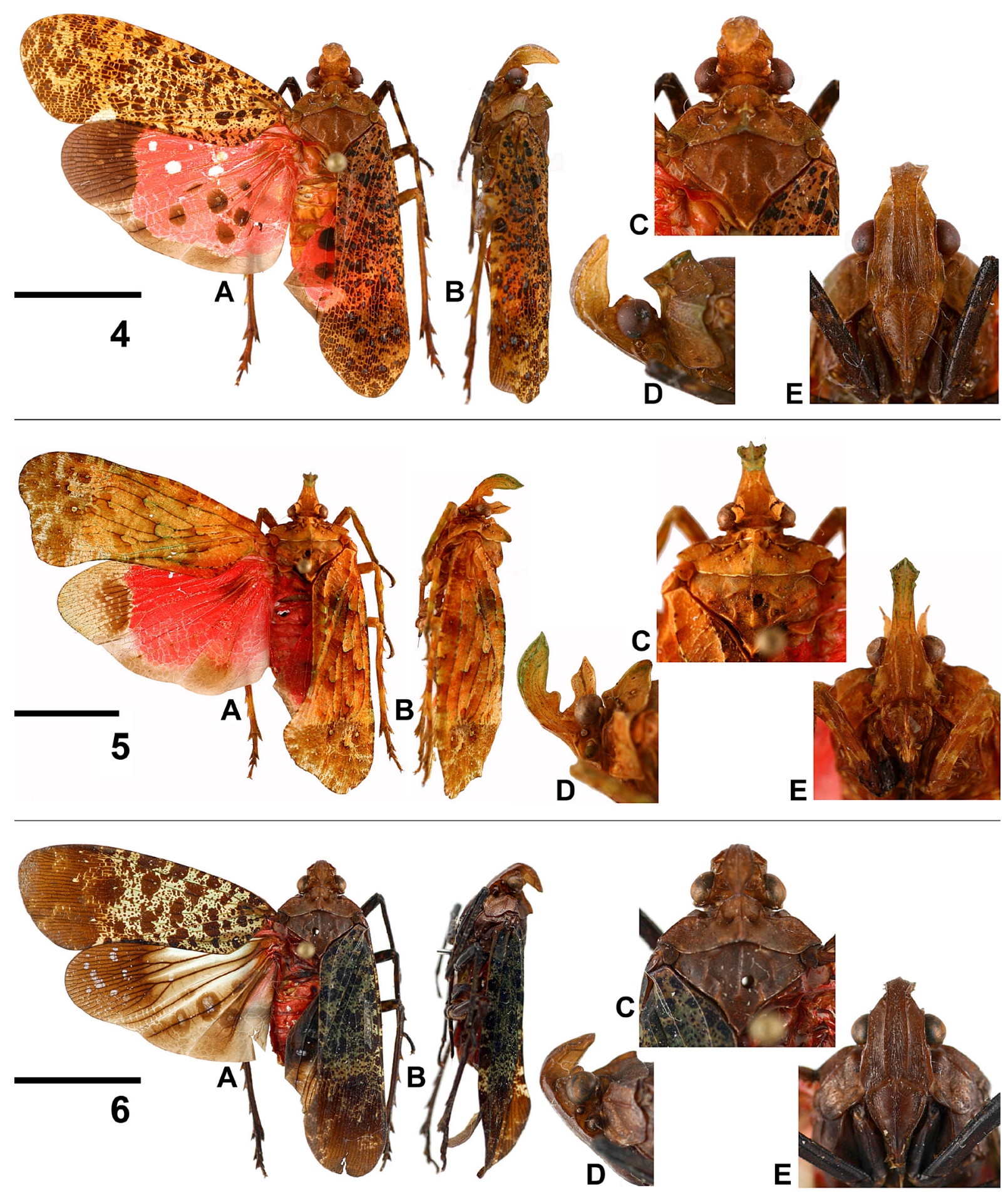

Figs 4-6. - 4. Belbina falleni. 5. B. foliacea. 6. B. laetitiae sp. nov. - A. Habitus, dorsal view. B. Habitus, lateral view. C. Vertex, pro- and mesonotum, dorsal view. D. Head and prothorax, lateral view. E. Frons, normal view. - Scale bar: $10 \mathrm{~mm}$ (C-E not to scale). 

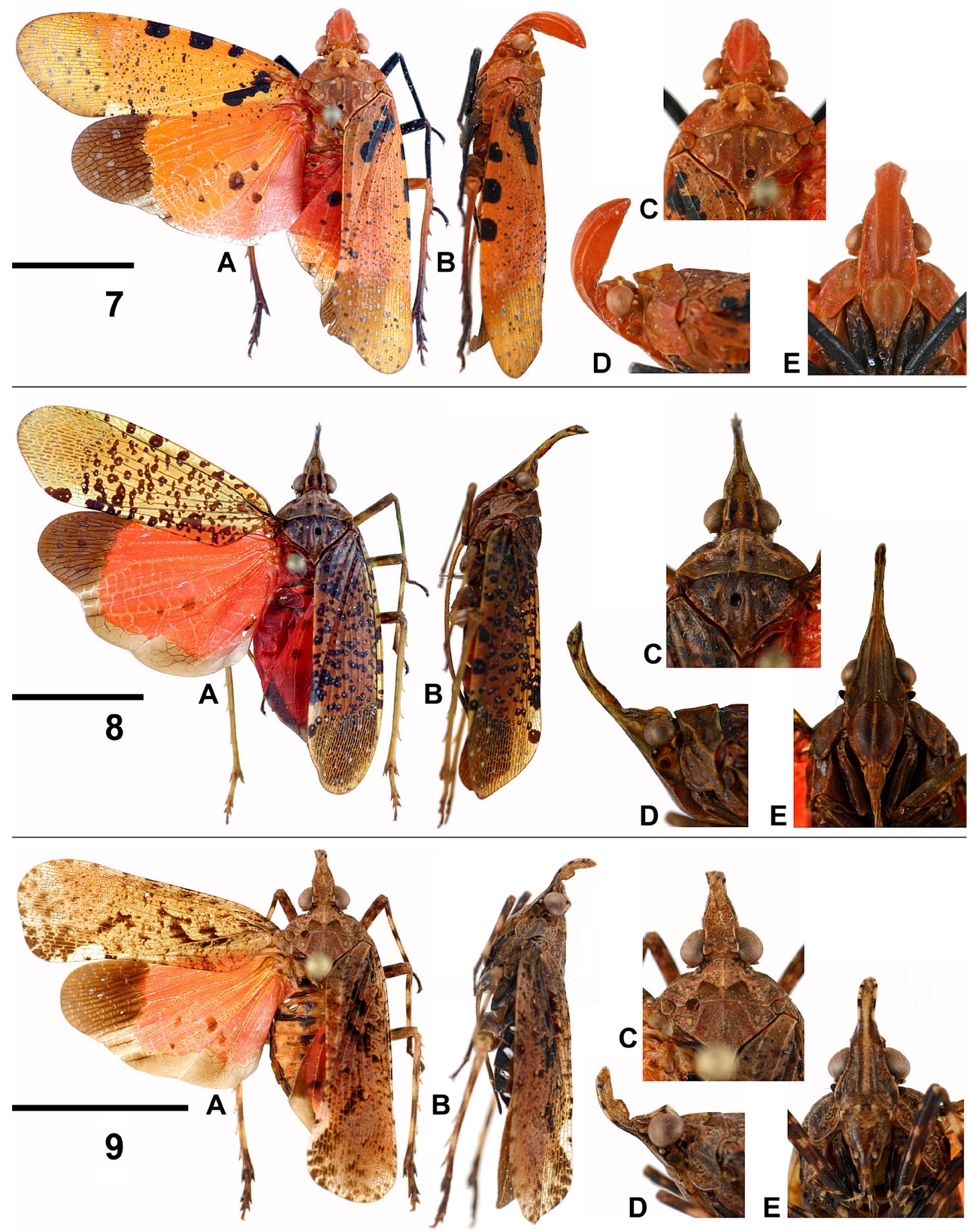

Figs 7-9. - 7. Belbina lambertoni. 8. B. madagascariensis. 9. B. nympha. - A. Habitus, dorsal view. B. Habitus, lateral view. C. Vertex, pro- and mesonotum, dorsal view. D. Head and prothorax, lateral view. E. Frons, normal view. - Scale bar: $10 \mathrm{~mm}$ (C-E not to scale). 

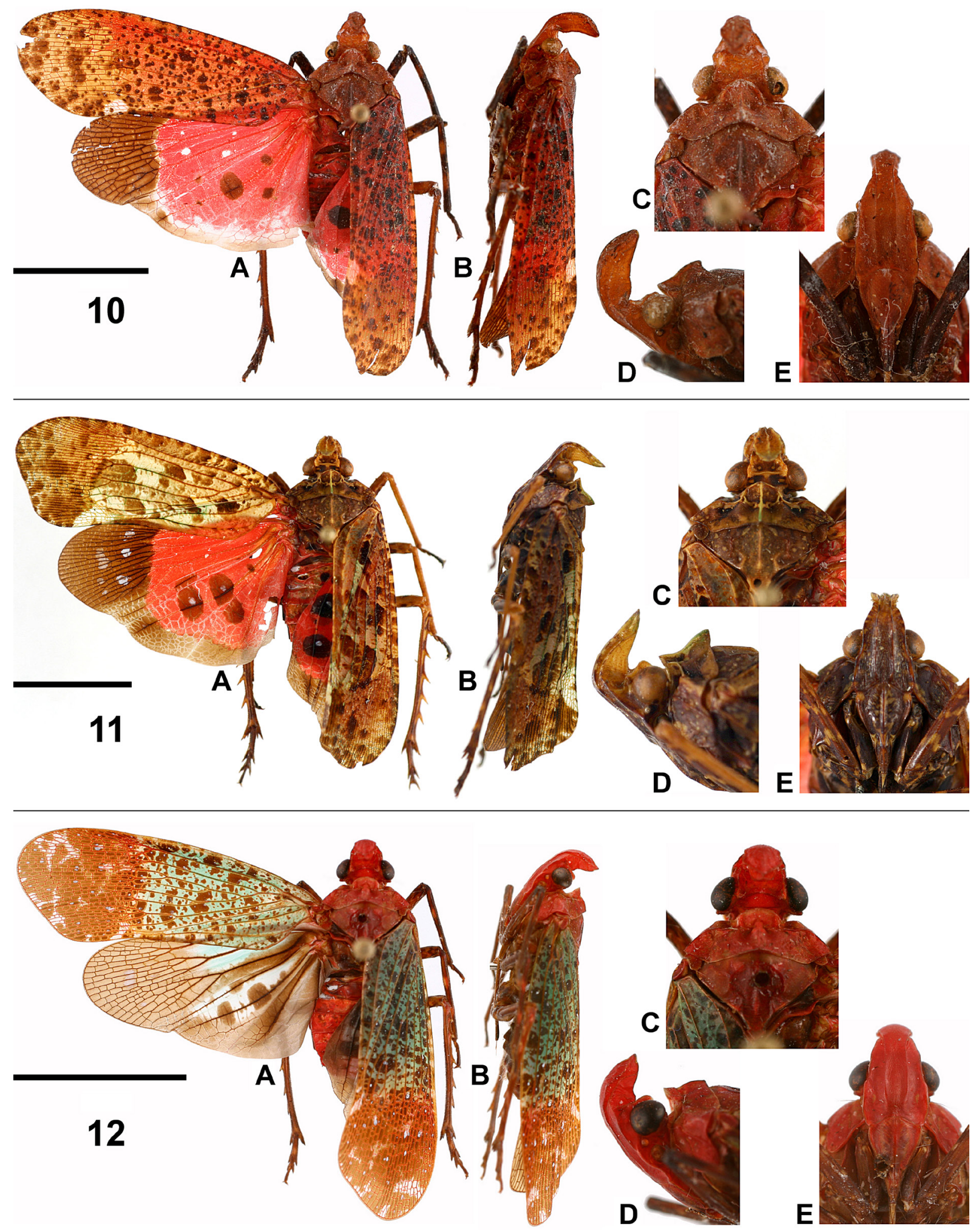

Figs 10-12. - 10. Belbina pionneaui. 11. B. recurva. 12. B. servillei. - A. Habitus, dorsal view. B. Habitus, lateral view. C. Vertex, pro- and mesonotum, dorsal view. D. Head and prothorax, lateral view. E. Frons, normal view. - Scale bar: $10 \mathrm{~mm}$ (C-E not to scale). 
Belbina bergrothi (Schmidt, 1911) comb. nov.

Figs 1A-E, 13-14, 36, 46

Cornelia bergrothi Schmidt, 1911: 242 (type in SDEI).

Cornelia bergrothi - Jacobi 1917: 526 (listed). — Metcalf 1947: 122 (catalogued). — Lallemand 1959: 88, fig. 34 (key, description, lateral view of head). - Constant 2004b: 31 (listed).
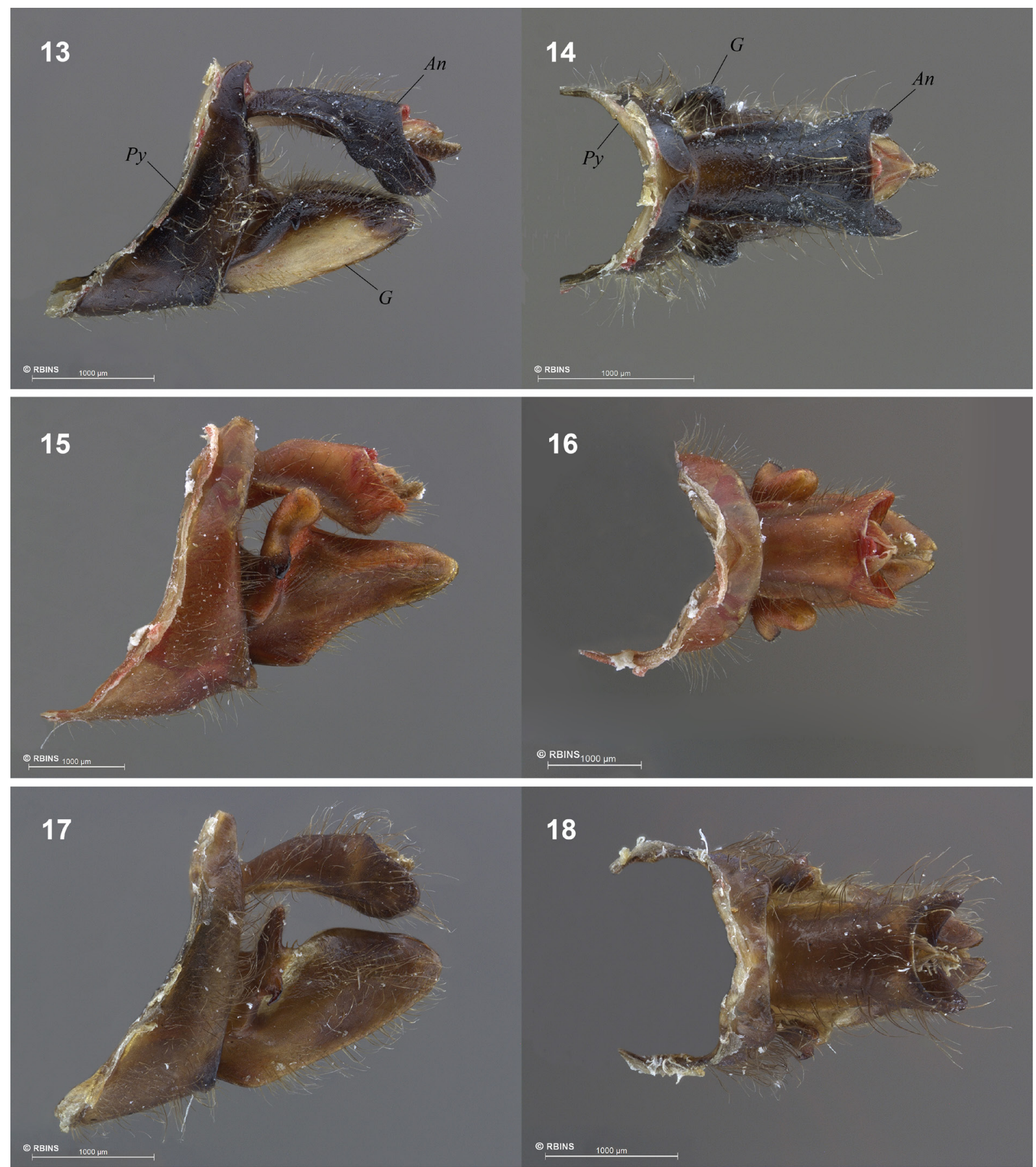

Figs 13-18. Male genitalia. - 13-14. Belbina bergrothi. 13. Lateral view. 14. Dorsal view. - 15-16. B. bloetei. 15. Lateral view. 16. Dorsal view. - 17-18. B. bourgoini sp. nov. 17. Lateral view. 18. Dorsal view. $-A n=$ anal tube, $P y=$ pygofer, $G=$ gonostylus. Photographs by Y. Laurent $\&$ I. Bachy. 


\section{Diagnostic characters}

(1) disc of hind wings orange or red (Fig. 1A); (2) 2 black patches on mesonotum (Fig. 1C); (3) size less than $22 \mathrm{~mm}$ long; (4) cephalic process directed dorsad, narrow in anterior view (Fig. 1D-E).

LT: $\widehat{~}(\mathrm{n}=3) 17.8 \mathrm{~mm}(17.0-19.0)$; 우 $(\mathrm{n}=2) 20.5 \mathrm{~mm}(20.0-21.0)$.
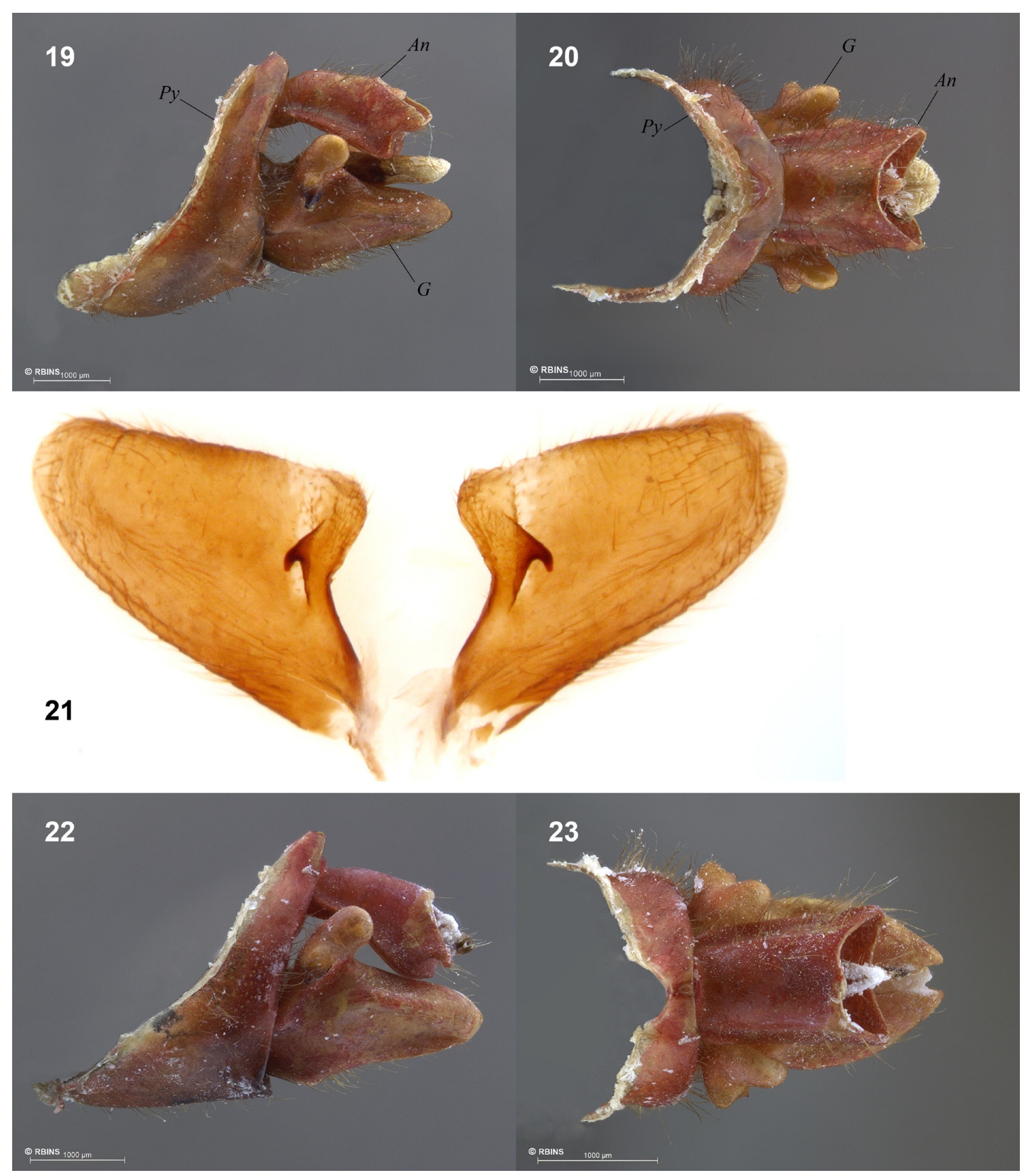

Figs 19-23. Male genitalia. - 19-20. Belbina falleni. 19. Lateral view. 20. Dorsal view. - 21. B. foliacea, gonostyli, normal view. - 22-23. B. laetitiae sp. nov. 23. Lateral view. 24. Dorsal view. $A n=$ anal tube, $P y=$ pygofer, $G=$ gonostylus. Photographs by Y. Laurent $\&$ I. Bachy. 


\section{Material examined}

\section{Holotype}

MADAGASCAR: + (on photographs), [Madagasc. Amber Geb.] [Holotypus] [Cornelia Bergrothi Schmidt + Edm. Schmidt determ. 1911] [Coll. Breddin] [Dtsch. Entomol. Institut Berlin], Montagne d'Ambre (Ambohitra), 12³0' S, 49¹0’ E (SDEI).
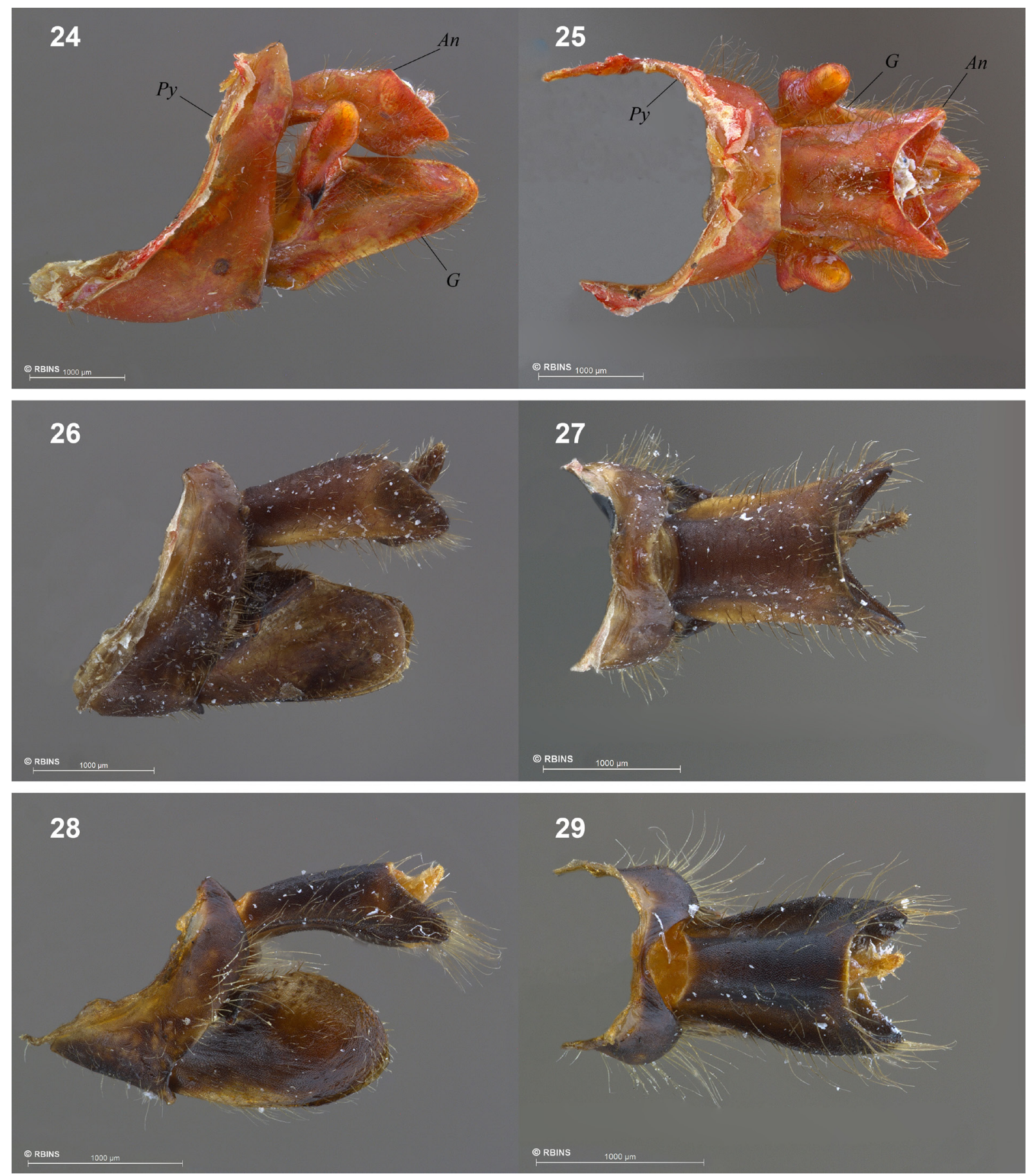

Figs 24-29. Male genitalia. - 24-25. Belbina lambertoni. 24. Lateral view. 25. Dorsal view. - 2627. B. madagascariensis. 26. Lateral view. 27. Dorsal view. - 28-29. B. nympha. 28. Lateral view. 29. Dorsal view. $-A n=$ anal tube, $P y=$ pygofer, $G=$ gonostylus. Photographs by Y. Laurent \& I. Bachy. 


\section{Additional material}

MADAGASCAR: 1 đ̄, 1 क , E Madagascar, Massif du Marojejy (rés. nat. intégr. 12), 1300 m, 2-8 Dec. 1972, A. Peyrieras, 14²6’ S, 4944’ E (MNHN); 1 đo, same data, 4 Dec. 1972 (RBINS); 1 + , same data, 12 Dec. 1972 (RBINS); 1 \&, Fianarantsoa province, Parc National Ranomafana, Belle Vue et Talatakely,
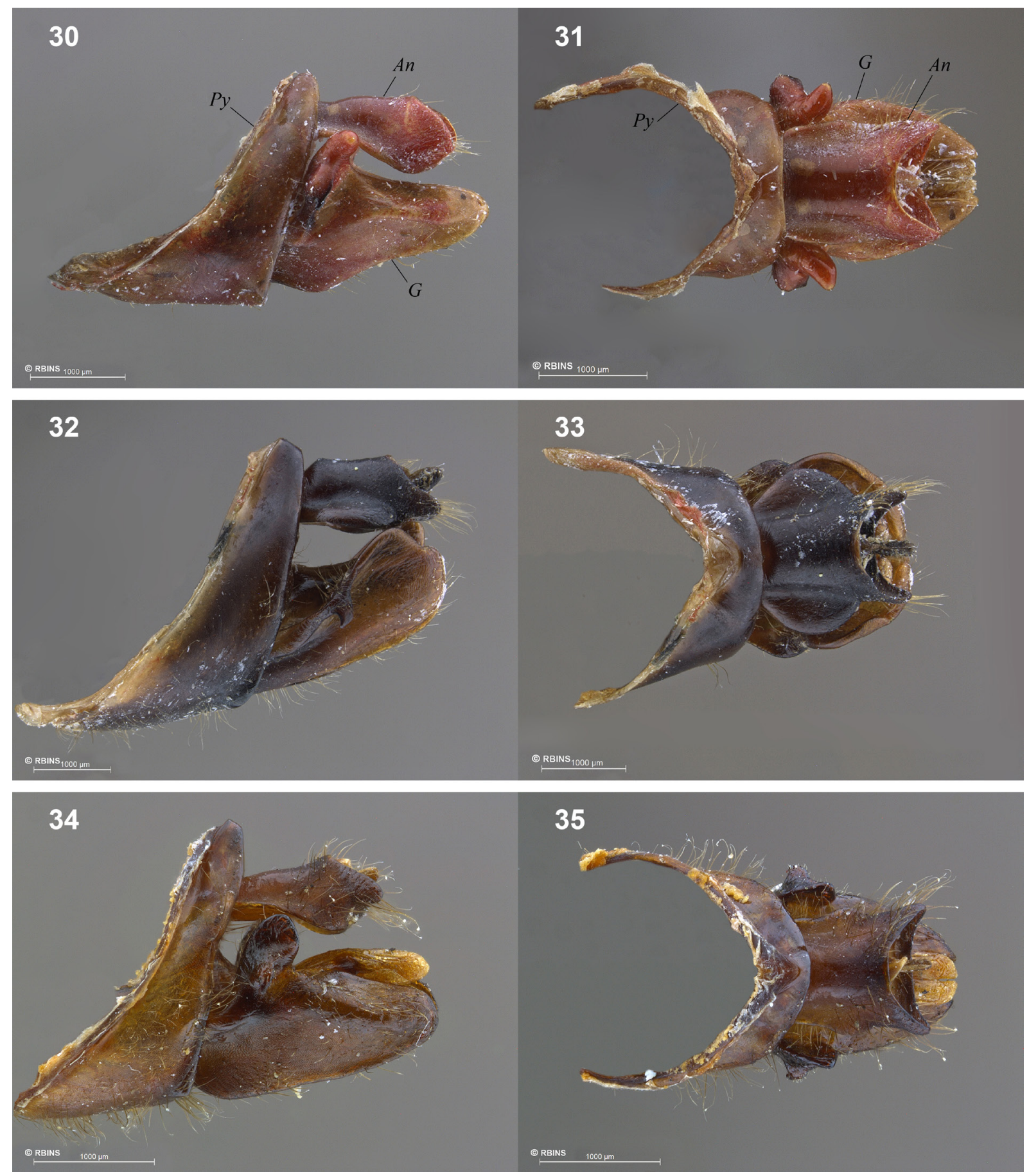

Figs 30-35. Male genitalia. - 30-31. Belbina pionneaui. 30. Lateral view. 31. Dorsal view. - 32-33. B. recurva. 32. Lateral view. 33. Dorsal view. - 34-35. B. servillei. 34. Lateral view. 35. Dorsal view. $-A n=$ anal tube, $P y=$ pygofer, $G=$ gonostylus. Photographs by Y. Laurent $\&$ I. Bachy. 

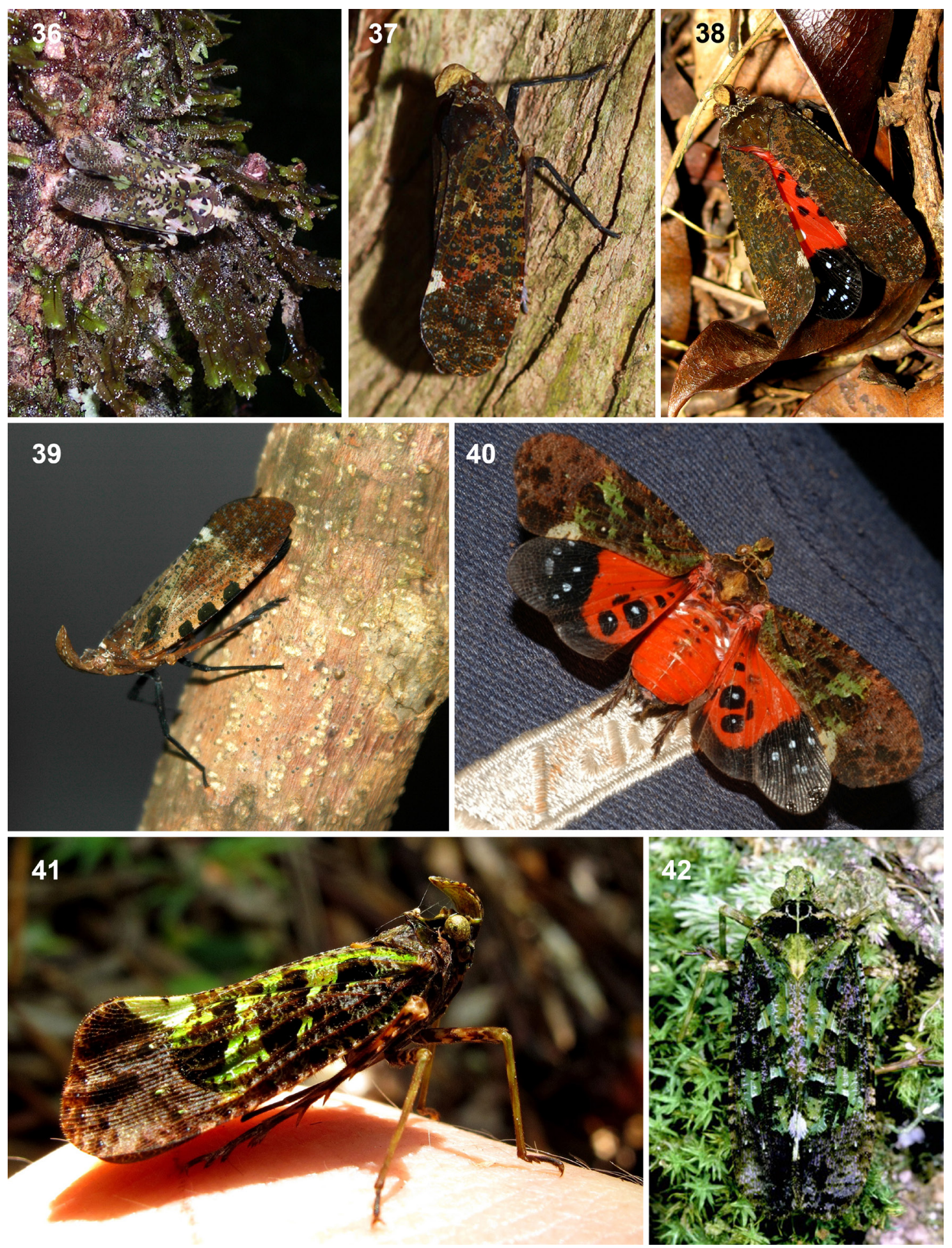

Figs 36-42. Belbina in natura. - 36. B. bergrothi. Vohimana, 4 Jan 2006, photograph by N. Cliquennois. -37-38. B. falleni. 37. Montagne d'Ambre, Joffreville, 2009, photograph by R.A. Butler. 38. Montagne d'Ambre, 27 Oct. 2009, photograph by N. Cliquennois. - 39. B. lambertoni, §̂, Berenty, 15 Nov. 2008, photograph by J. Cryan. - 40-42. B. recurva. 40. Marojejy, Cascade Humbert, 22 Nov. 2005, photograph by D. C. Lees. 41. Anajanaharibe Sud, 2 May 2010, photograph by B. Rowe. 42. Masoala Peninsula, 30 May 2009, photograph by D. Fenolio (C 2011 Danté Fenolio/www.anotheca.com, with permission). 
$21^{\circ} 15.99^{\prime} \mathrm{S} 47^{\circ} 25.21^{\prime} \mathrm{E}, 1020 \mathrm{~m}, 21-28$ Jan. 2002, Malaise trap, secondary forest, R. Harin'Hala

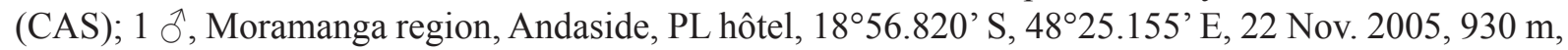
Bourgoin, Ouvrard, Attié, Soulier-Perkins (MNHN); 1 , , no data (FSAG); 1 q, Antananarivo province, 46 km NE of Ankazobe, Ambohitantely, $18^{\circ} 11.88^{\prime}$ S, 47 $7^{\circ} 16.89^{\prime}$ E, Malaise trap in sclerophyl forest, 700 m, 16-27 Jan. 2005, Irvin \& Harin'Hala (CAS); 1 ô, route d'Anosibe, 11 Nov. 1961 (MHNL).

\section{Examined on photograph}

MADAGASCAR: 1 specimen, Vohimana, 4 Jan. 2006, 13:35, Nicolas Cliquennois (Fig. 36), 1855’ S, $48^{\circ} 30^{\prime} \mathrm{E}$.

\section{Male genitalia}

Black with gonostyli showing large, basoventral ochraceous patch (Fig. 13); pygofer higher than long and with posterior margin sinuate in lateral view (Fig. 13); anal tube elongate, 1.6 times longer than broad at apex and with lateral margins sinuate in dorsal view (Fig. 14); gonostyli elongate, 2.4 times longer than high, not surpassing apex of anal tube and acutely rounded at apex in lateral view (Fig. 13); dorsal margin of gonostyli projecting laterally from base to midlength and with strong tooth directed ventrally (Figs 13-14); ventral margin and apical half of dorsal margin broadly rounded in lateral view (Fig. 13).

\section{Remarks}

Male genitalia without basodorsal process on gonostyli.

Belbina bergrothi can be separated (1) from $B$. recurva by not having the margins of the anal tube produced into a semi-circular lateral plate; (2) from B. madagascariensis and B. nympha by having the gonostyli acutely rounded apically and more elongate; (3) from $B$. foliacea by not having the gonostyli angulose above mediodorsal tooth.

\section{Distribution}

See Fig. 46.

Belbina bloetei Lallemand, 1959

Figs 2A-E, 15-16, 46

Belbina blotei Lallemand, 1959: 92, fig. 40a-b (lateral view of head, wing venation) (type in RMNH).

Belbina blotei - Constant 2004b: 31 (listed).

\section{Note}

The species epithet refers to the Dr H.C. Blöte (RMNH) and is emended following the article 32.5.2.1 of ICZN (1999).

\section{Diagnostic characters}

(1) disc of hind wings red (Fig. 2A); (2) size more than $26 \mathrm{~mm}$; (3) cephalic process projecting dorsad, broad (Fig. 2D-E); (4) ground colour of tegmina and head pale rosy brown; (5) rectangular pale patch on clavus (Fig. 2A, C).

LT: $\widehat{\partial}(\mathrm{n}=1) 27.0 \mathrm{~mm} ;$; $(\mathrm{n}=1) 29.5 \mathrm{~mm}$. 


\title{
Material examined
}

\section{Holotype}

MADAGASCAR: $q$ (examined on photographs), [Madagascar, coll. Lambert.] [environs de Tananarive] [Type] [Belbina blotei Lall., V. Lallemand det., 195] [RMNH.INS.780532], Tananarive (Antananarivo), $18^{\circ} 55^{\prime} \mathrm{S}, 47^{\circ} 31^{\prime}$ E (RMNH). - Note: "Lambert" = Lamberton.

\section{Paratypes}

MADAGASCAR: 1 q (examined on photographs), [Madagascar, rec. Lamberton] [environs de Tananarive] [Belbina blotei Lallemand, V. Lallemand det., 195] [Paratype] [RMNH.INS.780531] $(\mathrm{RMNH}) ; 1$ ${ }^{2}, 1$ \&, [environs de Tananarive] (FSAG). Note: Lallemand (1959) stated that all types are deposited in RMNH but he actually retained 2 paratypes in his collection (now in FSAG).

\section{Additional material}

MADAGASCAR: 1 đ', Mahajanga Prov., Forêt de Tsimembo, $8.7 \mathrm{~km} 336^{\circ}$ NNW of Soatana, $19^{\circ} 1{ }^{\prime} 17^{\prime \prime}$ S, 442'ㄷ' E, 20 m, 21-25 Nov. 2001, at light in tropical dry forest, Fisher, Griswold et al. (CAS); 2 우, near Tananarive, Lamberton (RBINS); 2 우오, Morondava à Mahabo, Last 1854-91, 20²0' S,

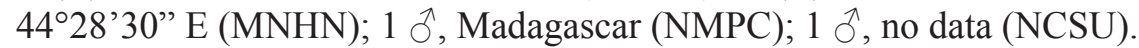

1 ㅇ, erroneously labelled Soekaboemi, Java (INHS).

\section{Male genitalia}

Dark red (Figs 15-16); pygofer higher than long and with posterior margin concave in middle in lateral view (Fig. 15); anal tube slightly elongate, 1.16 times longer than broad at apex and with lateral margins bisinuate in dorsal view (Fig. 16); margin of anal opening pointed posteriorly (Fig. 15) and hiding lateral margin apically in dorsal view (Fig. 16); gonostyli elongate, 1.18 times longer than high (dorsal process included), strongly surpassing apex of anal tube and acutely rounded at apex in lateral view (Fig. 15); ventral margin straight on basal 1/5, then strongly excavate (Fig. 15); dorsal margin with basal strong digitiform process projecting laterodorsally, strong hook laterally at middle of process projecting posteroventrally and posterior margin of process excavate between apex and hook (Fig. 15); apex of digitiform process rounded and broad in dorsal view (Fig. 16).

\section{Remarks}

Belbina bloetei is a member of the falleni+ group, showing strong basodorsal digitiform process on gonostyli. It can be separated (1) from B. falleni, B. laetitiae sp. nov., B. lambertoni and B. pionneaui by the more strongly concave ventral margin of the gonostyli in lateral view; (2) from $B$. falleni by the less excavate dorsal margin of the gonostyli in dorsal view; (3) from B. laetitiae sp. nov. and B. lambertoni by the more acute apex of the gonostyli in lateral view; (4) from B. pionneaui by the more rounded apex of the basodorsal digitiform process of the gonostyli.

\section{Distribution}

See Fig. 46.

\author{
Belbina bourgoini sp. nov. \\ Figs 3A-E, 17-18, 47 \\ urn:1sid:zoobank.org:act:266C852F-6F78-48E8-AC72-3A286E350836
}

\section{Diagnostic characters}

(1) disc of hind wings light white-bluish (Fig. 3A); (2) small-sized (less than $22 \mathrm{~mm}$ long); (3) tegmina brown with dark red-brown band (Fig. 3A); (4) head, pro- and mesonotum brown (Fig. 3C-E). 


\section{Etymology}

The species is dedicated to Prof. Thierry Bourgoin (MNHN), in acknowledgement of his permanent help and support from the beginning of the work of the author.

\section{Material examined}

\section{Holotype}

MADAGASCAR: $\widehat{\jmath}$, [Marojezy XII-1972] [Museum Paris, Madagascar Est, mission C.N.R.S., R.C.P. $\left.\mathrm{n}^{\circ} 225\right], 14^{\circ} 26^{\prime} \mathrm{S}, 49^{\circ} 44^{\prime} \mathrm{E}$ (MNHN).

\section{Paratypes}

MADAGASCAR: $1 \hat{\jmath}$, [Madagascar Est, Massif du Marojejy (rés. nat. intégr. 12) 1300m, 2/8-XII1972, A. Peyrieras] [Museum Paris] (RBINS); 1 đ̃, [Coll. P. Bleuzen, Lakato, Madagascar, 13.I.1962], $19^{\circ} 11^{\prime} \mathrm{S}, 48^{\circ} 26^{\prime} \mathrm{E}$ (MHNL).

\section{Description}

LT: Љ $(\mathrm{n}=2) 19.2 \mathrm{~mm}(19.0-19.5)$.

HEAD. Yellow-brown sometimes suffused with red (Fig. 3C-E); vertex with hind margin and sides strongly carinate (Fig. 3C); sides of vertex bisinuate in lateral view (Fig. 3D); frons with 2 carinae extending on sides of cephalic process (Fig. 3E); cephalic process about 1.5 times as long as diameter of eye, projecting dorsad to posterodorsad (Fig. 3D); apical half carinate anteriorly and strongly emarginate laterally (Fig. 3E); posterior side of process with 2 longitudinal, sinuate carinae; lateral oblique carina between vertex and frons before eye (Fig. 3D); postclypeus with sides strongly carinate and obsolete median carina; anteclypeus with strong median carina (Fig. 3E); labium very elongate, surpassing hind coxae but not reaching apex of abdomen.

THorax. Yellow-brown varied with irregular paler spots (Fig. 3C-D); pronotum carinate anteriorly; sinuate carinae at anterior margin of disc, reaching anterior margin before median carina (Fig. 3C); median carina strong, sinuate in lateral view; hind margin strongly elevated above level of mesonotum medially (Fig. 3D); impressed point on disc on each side of carina; obsolete tubercles at each side of disc (Fig. 3C); sides of prothorax longitudinally carinate; lateral lobes of pronotum rounded posteriorly (Fig. 3D-E); mesonotum with median carina stopped at scutellum posteriorly; strongly sinuate carina on each side of disc, Y-shaped anteriorly; scutellum transversely wrinkled (Fig. 3C).

Tegmina (Fig. 3A). Pale yellow-brown with irregular brown-black markings; ground colour red-brown on middle; clavus paler; white marking along sutural margin at level of nodal line; costal margin slightly rounded; apical angles rounded; sutural and apical margins sinuate, the latter oblique; ratio $\mathrm{LTg} / \mathrm{BTg}=$ 2.6.

HinDwings (Fig. 3A). Black-brown with large, light white-buish discal patch of basal half, reaching costal margin and extending posteriorly along vein $\mathrm{Cu}$ without reaching sutural margin; black-brown elongate marking basally along vein $\mathrm{M}$; big black spot along vein $\mathrm{PCu}$ followed by 1-2 smaller spots; apex rounded, sutural margin sinuate.

LEGS (Fig. 3A). Elongate and slender; femora brown with 3-4 narrow, sinuate and often incomplete pale yellow rings; pro- and mesotibiae brown with 2 pale yellow rings; metatibiae brown with pale yellow markings at spines; pro- and mesotarsi black-brown; first metatarsomere pale yellow-brown on basal $2 / 3$; rest of metatarsi brown; metatibiae with 6-7 lateral and 7 apical spines; first metatarsomere with 9 apicoventral spines. 
AвDOMEN (Fig. 3A). Brown, darker ventrally.

\section{Male genitalia}

Dark brown (Figs 17-18); pygofer higher than long and with posterior margin nearly straight, slightly sinuate dorsally in lateral view (Fig. 17); anal tube elongate, 1.6 times longer than broad at apex and with lateral margins bisinuate in dorsal view (Fig. 18), slightly curved ventrally and with apex broadly rounded in lateral view (Fig. 17); gonostyli elongate, 1.6 times longer than high (dorsal process included), surpassing apex of anal tube and broadly rounded at apex in lateral view (Fig. 17); ventral margin straight, with strong angle at basal 1/8 (Fig. 17); dorsal margin with basal slender digitiform process projecting laterodorsally, pointed tooth laterally at middle of process projecting anteroventrally, apex of digitiform process narrowing apically (Fig. 17); apical $2 / 3$ of dorsal margin sinuate (Fig. 17).

\section{Remarks}

Belbina bourgoini sp. nov. can be separated (1) from all species of the B. falleni+ group by the brown colour of the genitalia, the more slender basodorsal digitiform process on the gonostyli and by having the gonostyli rounded at the apex, with the dorsal margin sinuate after the process; (2) from B. bergrothi, B. foliacea, B. madagascariensis and B. nympha by the basodorsal digitiform process on the gonostyli; (3) from B. servillei by having the digitiform basodorsal process of the gonostyli slender and narrow, not laminate.

\section{Distribution}

See Fig. 47.

Belbina falleni Stål, 1863

Figs 4A-E, 19-20, 37-38, 47

Belbina falleni Stål, 1863a: 233 (type in NMW).

Belbina vicina Lallemand, 1959: 90, fig. 38 (key, description and dorsal view of head and thorax) (type in FSAG). syn. nov.

Belbina falleni - Stål 1866: 144 (key, description). — Jacobi 1917: 527 (listed). — Metcalf 1947: 123 (catalogued). - Lallemand 1959: 93, fig. 41 (key, description and lateral view of head). - Constant 2004b: 31 (listed).

Belbina vicina - Constant 2004b: 31 (listed).

\section{Diagnostic characters}

(1) disc of hind wings red with black markings (Fig. 4A); (2) ground colour of tegmina pale brown (Fig. 4A); (3) sides of vertex laminate above eye but not foliaceous (Fig. 4C-D); (4) large-sized (more than 26 mm long); (5) cephalic process broad, strongly curved dorsad (Fig. 4D); (6) clavus with colour pattern similar to the rest of the tegmen (Fig. 4A).

LT: $\widehat{\jmath}(\mathrm{n}=5) 26.6 \mathrm{~mm}(26.0-27.0) ;$ 우 $(\mathrm{n}=7) 29.1 \mathrm{~mm}(28.5-30.2)$.

\section{Material examined}

Type material

MADAGASCAR: Holotype of Belbina falleni,, , [Madagascar, Coll. Signoret] [Falléni det. Signoret] [Type] (NMW).

MADAGASCAR: Holotype of Belbina vicina Lallemand, 1959, ô, [Manjakandriana, Madagascar] [Type.] [Belbina vicina Lall., V. Lallemand det., 1957], 1855' S, 47²4' E (FSAG). 


\section{Additional material}

MADAGASCAR: 1 , Manjakandriana (FSAG); $2 \widehat{\widehat{\partial}, 1}+$, near Tananarive, Lamberton, Tananarive

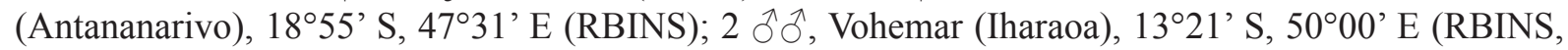
NCSU); 1 q, N Madagascar (BMNH); 1 \%, Montagne d'Ambre, Feb. 1930, Sicard, Montagne d'Ambre (Ambohitra), 12³0' S, 4910' E (MNHN); 1 , idem, Dec. 1930 (MNHN); 1 q, no locality, Apr. 1930, Sicard (MNHN); 1 , , Madagascar, coll. De Bergevin (MNHN); 4 우, Madagascar (2: MNHN, 2: NMW); 1 §̂, N Madagascar, $37 \mathrm{~km} \mathrm{~S}$ of de Vohémar, Analalava forest, $25 \mathrm{~m}, 10-18$ Dec. 1968, P. Viette \& P. Griveaud, 1336' S, 4959' E (MNHN); 1 $^{`}$, Diego-Suarez, coll. De Bergevin, Diègo Suarez (Ampanolahamirafy), $12^{\circ} 16^{\prime} \mathrm{S}, 4^{\circ} 17^{\prime} \mathrm{E}$ (MNHN); 1 을, Plateau de l'Ankarafantsika, W Madagascar, coll. De Bergevin 16 $16^{\prime}$ S, 46³5’ E (MNHN); 1 , , N Madagascar (BMNH); 1 ㅇ, no data (NCSU).

\section{Examined on photographs}

MADAGASCAR: 1 specimen, Montagne d'Ambre, 27 Oct. 2009, 15:05, Nicolas Cliquennois (Fig. 38); 1 specimen, Montagne d'Ambre, Joffreville (Ambohitra), 2009, Rhett A. Butler (Fig. 37).

\section{Male genitalia}

Dark red (Figs 19-20); pygofer higher than long and with posterior margin sinuate in lateral view (Fig. 19); anal tube slightly elongate, 1.27 times longer than broad at apex and with lateral margins bisinuate in dorsal view on apical half (Fig. 20); posterior margin notched in lateral view (Fig. 19), with hind margin of anal opening projecting posteriorly (Fig. 19) and hiding lateral margin apically in dorsal view (Fig. 20); gonostyli elongate, 1.36 times longer than high (dorsal process included), strongly surpassing anal tube and acutely rounded at apex in lateral view (Fig. 19); ventral margin straight on basal 1/5, then slightly sinuate (Fig. 19); dorsal margin with basal strong digitiform process projecting laterodorsally, strong hook laterally at middle of process projecting posteroventrally and posterior margin of process excavate between apex and hook (Fig. 19); apex of digitiform process rounded and broad in lateral view (Fig. 19), slightly compressed laterally in dorsal view (Fig. 20).

\section{Remarks}

Lallemand (1959) erroneously mentioned that the type of B. vicina is a female. However it is obvious that the type is a male because he stated that "genitalia have similar shape as those of $B$. pionneaui and B. lambertoni".

Lallemand (1959) described B. vicina based on a specimen of B. falleni presenting the cephalic process more strongly curved posteriorad than in another specimen he had identified in his collection as B. falleni; both specimens were from the same locality (Manjakandriana). Male genitalia are similar and intraspecific variability in the direction of the cephalic processs has been observed from series in several species of Belbina. For those reasons, B. vicina is here synonymized with B. falleni.

Belbina falleni is a member of the falleni+ group, showing a strong basodorsal digitiform process on the gonostyli. It can be separated (1) from B. bloetei by the less concave ventral margin of the gonostyli in lateral view; (2) from $B$. laetitiae sp. nov. and $B$. lambertoni by the laterally more strongly compressed digitiform process and the more acutely rounded apex of the gonostyli in lateral view; (3) from B. pioneaui by the more rounded apex of the basodorsal digitiform process of the gonostyli and the more strongly notched ventroapical margin of the anal tube under the anal opening in lateral view.

\section{Distribution}

See Fig. 47. 
Belbina foliacea Lallemand, 1950 comb. rev.

Figs 5A-E, 21, 47

Belbina foliacea Lallemand, 1950: 84 (type in FSAG).

Cornelia foliacea - Lallemand 1959: 87, fig. 32a-c (key, description, lateral view of head and male genitalia). - Constant 2004b: 31 (listed).

\section{Diagnostic characters}

(1) disc of hind wings red (Fig. 5A); (2) carina above eye strongly expanded dorsad into foliaceous process (Fig. 5C-E); (3) cephalic process strongly curved dorsad (Fig. 5D); (4) tegmina variegated brown-olivaceous; (5) veins of tegmina elevated (Fig. 5A).

LT: $\hat{o}(\mathrm{n}=1) 24.0 \mathrm{~mm}$; + $(\mathrm{n}=1) 29.9 \mathrm{~mm}$.

\section{Material examined}

\section{Holotype}

MADAGASCAR: $\hat{0}$, [Maromandia, Madagascar, Lamberton] [Type.] [Cornelia foliacea Lall., V. Lallemand det., 1954], 1856’ S, 4903’ E (FSAG).

\section{Paratype}

MADAGASCAR: 1 , no label, probably same data as holotype.

\section{Male genitalia}

The male genitalia were dissected and drawn by Henry Synave for Lallemand's revision (1959). Only one gonostylus and the phallic complex were illustrated. The organs were preserved in a small glass vial under the specimen. The anal tube is missing and the pygofer is severely damaged. As it has been treated with potassium hydroxide, it is not possible to know the original colour.

Gonostyli elongate, 1.7 times longer than high and broadly rounded at apex in lateral view; ventral margin nearly straight; dorsal margin strongly sinuate basally and with a strong angle at basal third, then straight; strong lateral tooth directed posteroventrally along dorsal margin under angle (Fig. 21).

\section{Remarks}

Male genitalia without a baso-dorsal process on the gonostyli.

Belbina foliacea can be separated from B. bergrothi, B. madagascariensis, B. nympha and B. recurva by the strong angle above the medio-dorsal tooth and the broadly rounded apex of the gonostyli.

\section{Distribution}

See Fig. 47.

Belbina laetitiae sp. nov.

Figs 6A-E, 22-23, 43-45, 48

urn:1sid:zoobank.org:act:87E89C54-19CC-48C8-A2B0-E6CE95E8410A

Belbina servillei - Lallemand 1959: 88, fig. 36a-c (key, description, lateral view of head and pronotum, male genitalia) [non Belbina servillei (Spinola, 1839)]. 


\section{Diagnostic characters}

(1) disc of hind wings milky, base and anal lobe suffused with red (Fig. 6A); (2) head, pro- and mesonotum brown (Fig. 6C-E); (3) ground colour of tegmina bluish green (Fig. 6A); (4) large-sized (more than 24 $\mathrm{mm}$ long); (5) cephalic process broad, projecting dorsad to posterodorsad (Figs 6D-E).

LT: §̊ ( $\mathrm{n}=8) 24.3 \mathrm{~mm}(23.2-25.4)$; 우 $(\mathrm{n}=11) 26.8 \mathrm{~mm}(25.1-28.4)$.

\section{Etymology}

Dedicated to Mrs Laetitia Despontin, the mother of my children Emilie and Guillaume.

\section{Material examined}

\section{Holotype}

MADAGASCAR: ${ }^{\Uparrow}$, [Madagascar, La Mandraka, xii.2000] [Coll. I.R.Sc.N.B., Don T. Neef de Sainval, I.G. 30.731], 1855' S, 4756’ E (RBINS).

\section{Paratypes}

MADAGASCAR: $1 \hat{\jmath}$, same data as holotype; $1 \hat{\jmath}$, [Coll. I.R.Sc.N.B. Madagascar Est, district

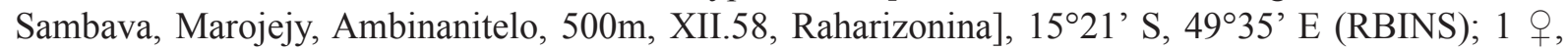
[Coll. I.R.Sc.N.B. Madagascar Est, district Sambava, Marojejy, Ambodifiakarana, 1600m, XII;58, Raharizonina], $17^{\circ} 12^{\prime}$ S, $48^{\circ} 11^{\prime}$ E (RBINS); 1 \&, [Coll. I.R.Sc.N.B. Madagascar Sud-Est, S. kavondro, $225 \mathrm{~m}$, Forêt Isaka, Fort Dauphin, 24.II.58, P. Griveaud], Fort-Dauphin (Tolaoaro), 2502’ S, $47^{\circ} 00^{\prime}$ E (RBINS); 1 \&, [CASENT 3004835] [Tananarive Madagascar, Oct., 1949], Tananarive (Antananarivo), $18^{\circ} 55^{\prime} \mathrm{S}, 47^{\circ} 31^{\prime} \mathrm{E}$ (CAS); $1 \mathrm{O}^{\top}$, [Madagascar, Antongil B., Mocquerys] [Madagascar] [1204] [Coll. Hungarian Nat. Hist. Museum, Budapest], $15^{\circ} 45^{\prime} \mathrm{S}, 49^{\circ} 50^{\prime} \mathrm{E}$ (HMNH); 4 + $\circ$, [Madagascar, Antongil B., Mocquerys] [Coll. Hungarian Nat. Hist. Museum,Budapest] (HMNH); 1 , , [212, 69] [Museum Paris, Madagascar, 151 et suiv.-69] [Museum Paris, MNHN (EH), 3948] (MNHN); 1 \%, [Goudot, Madagascar, 1832] [Museum Paris, MNHN (EH), 3947] (MNHN); 1 ô, [Madagascar, Fenerive, E. Perrot] [Museum Paris, Oberthur 101-96] [Museum Paris, MNHN (EH), 3950] Fenerive (Fenoarivo Atsinanana), $17^{\circ} 22^{\prime}$ S, 492' E (MNHN); 1 q, [Museum Paris, Madagascar, côte Ouest, Grandidier 1808-71] [Plateau de l'Ankarafantsika, Madagascar (Ouest)] [Museum Paris, MNHN (EH), 3949], 16¹6' S, 46³5' E $(\mathrm{MNHN}) ; 1$ $\delta^{2}$, [Madagascar Est, district de Maroantsetra, station forestière de Farankaraina, route de Navana, km 16.5, vallée d'Antoroka 100m, 8/18-I-1964, P. Viette] [Museum Paris, MNHN (EH), 3951], $15^{\circ} 26^{\prime}$ S, 4944' E (MNHN); 1 ô, 1 ㅇ, [Mus. Roy. Afr. Centr., Madagascar Est: Ambodivoangy, I.1960, J. Vadon] [Belbina servillei Spin., H. Synave det. 1963], 15¹7’50” S, 49³6’47” E, (MRAC); 1 ${ }^{\top}$, [Coll. Mus. Tervuren, N.E. Madagascar: Ambodivoangy, VIII.1961, J. Vadon] [Belbina servillei Spinola, H. Synave det. 1963] (MRAC); 1 q, [Coll. Mus. Tervuren, N.E. Madagascar: Ambodivoangy, VIII.1961, J. Vadon] (MRAC); 1 \%, [Madagascar: Fampanambo, III.1961, J. Vadon] [Belbina servillei

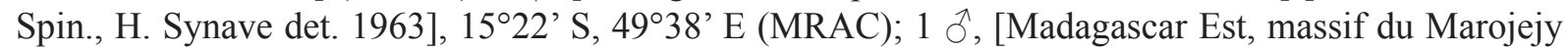
(rés. nat. intégr. 12) 600 m, 9/12-XII-1972, A. Peyrieras] [Museum Paris, MNHN (EH), 3952], 14²6' S, 4944' E, (MNHN); 1 + , [Madagascar Est, massif du Marojejy (rés. nat. intégr. 12)] [Ambatomitatao, 400 m, A. Peyrieras, I.1973] [Museum Paris, MNHN (EH), 3953], 1347’30» S, 4951' E (MNHN); 1 , [Madag., (on the reverse) 91 158] [Belbina nov. sp. trop abimé pour être décrit, dét. V. Lallemand 19] (BMNH); 1 ô, [Madagascar, collection Le Moult] [Belbina servillei Spin., V. Lallemand det.]

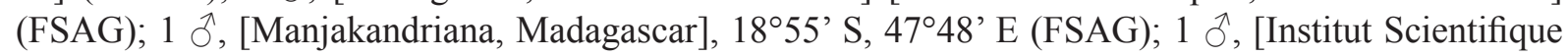
Madagascar] [Madagascar Sud, dct. Fort Dauphin, Antanimora, 300m, xii-59, Raharizonina] [Belbina

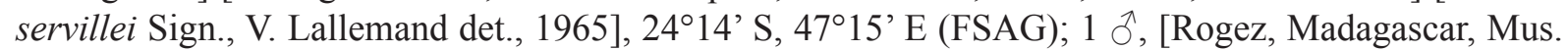
Praha] [Enchophora sp.] (NMPC); 1 $\hat{\jmath}$, [Madagascar, Collection Le Moult] [Ne pas étaler, défectueux] (NCSU); $2 \hat{\jmath} \hat{\jmath}$, [Madagascar, Marsantsetra], Marsantsetra is a misspelling of Maroantsetra (NCSU). 


\section{Examined on photograph}

MADAGASCAR: 1 specimen (Figs 43-45), Ile Sainte Marie, 25 Nov. 2011, Paul Bertner, 1650’ S, $49^{\circ} 55^{\prime} \mathrm{E}$.

\section{Description}

HEAD. Brown, sometimes slightly suffused with red (Fig. 6C-E); vertex with hind margin strongly carinate and sides laminate, bisinuate in lateral view and elevated above eye (Fig. 6C-D); frons longitudinally wrinkled with 2 carinae extending on sides of cephalic process (Fig. 6E); cephalic process slightly more than twice as long as diameter of eye, projecting posterodorsad to dorsad (Fig. 6D); apical half of process lanceolate in anterodorsal view and with median carina anteriorly (Fig. 6C, E); posterior side of process with 2 carinae fused before apex; strongly sinuate carina under side of vertex, not reaching eye (Fig. 6D); postclypeus with sides strongly carinate and median carina; anteclypeus with strong median carina (Fig. 6E); labium very elongate, surpassing hind coxae but not reaching apex of abdomen.

THORAX. Brown with mesonotum and meso- and metapleura red (Fig. 6C-E); pronotum with strong median carina sinuate in lateral view (Fig. 6C-D); hind margin strongly elevated above level of mesonotum medially; sides of prothorax longitudinally carinate; lateral lobes of prothorax rounded posteriorly (Fig. 6D); mesonotum (Fig. 6C) with median carina stopped posteriorly before scutellum; strongly sinuate carina on each side of disc, sometimes divided into external, sinuate carina and internal, posterior, angulous carina; scutellum transversely wrinkled.

TEgmina (Fig. 6A). Green-brown to pale olivaceous-brown with irregular, dense, black-brown to black markings; apical $1 \frac{1}{3}$ brown-black with large, unprecise, darker markings and some minute, whitish spots; small white patch along sutural margin at nodal line with black spot in middle; costal and apical margins slightly rounded, the latter oblique; apical angles rounded; sutural margin sinuate.

HIND wINGS (Fig. 6A). Smoky brown-black, darker on apical 1/3; anal lobe and base suffused with red; milky patch on basal $2 / 3$ from costal margin to vein $\mathrm{M}$ or $\mathrm{Cu}$; veins darker than ground colour; 4-6 dark brown-black ocelli on clavus with round, waxy spot in middle; irregular white waxy spots on apical $1 / 3$ and on disc; apex rounded, sutural margin emarginate at $2 / 3$.
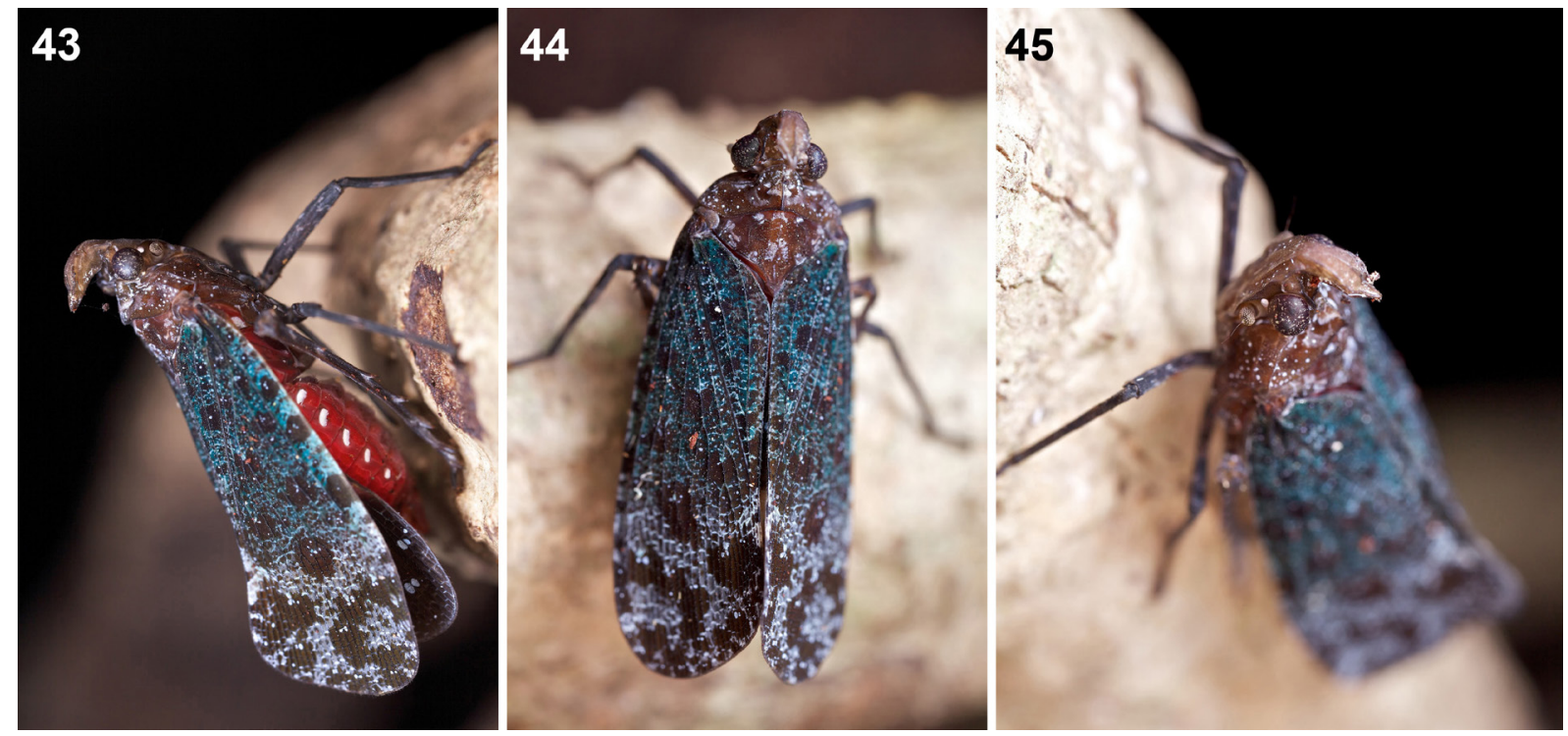

Figs 43-45. Belbina laetitiae sp. nov. in natura, Ile Sainte Marie, 25 Nov. 2011, photographs by Paul Bertner. 
LEGS (Fig. 6A). Elongate and slender; dark brown-black, with obsolete pale yellow-brown rings often only marked by small spots: $3-4$ rings on pro- and mesofemora, 2 on mesotibiae and on metafemora; spines of metafemora with pale yellow-brown spots near base; metatibiae with 5 lateral and 7 apical spines; 12 spines apicoventrally on first metatarsomere.

AвDomen (Fig. 6A). Bright red with 2 longitudinal rows of 4 black spots dorsally.

\section{Male genitalia}

Red (Figs 22-23); pygofer higher than long and with posterior margin slightly sinuate in lateral view (Fig. 22); anal tube slightly elongate, 1.39 times longer than broad at apex and with lateral margins nearly straight in dorsal view (Fig. 23); posterior margin strongly notched in lateral view (Fig. 22), with hind margin of anal opening projecting posteriorly and pointed in lateral view (Fig. 22), and hiding lateral margin apically in dorsal view (Fig. 23); gonostyli elongate, 1.22 times longer than high (dorsal process included, 1.72 times longer than high without process), surpassing anal tube and acutely rounded at apex in lateral view (Fig. 22); ventral margin straight on basal 1/5, then slightly sinuate (Fig. 22); dorsal margin, with basal strong digitiform process projecting laterodorsally and slightly curved posteriorly, strong hook laterally at middle of process projecting anteroventrally (Fig. 22); apex of digitiform process rounded and broad (Fig. 22-23).

\section{Remarks}

Belbina laetitiae sp. nov. is a member of the falleni+ group, showing a strong basodorsal digitiform process on the gonostyli. It can be separated (1) from B. bloetei by the less concave ventral margin and more rounded apex of the gonostyli in lateral view; (2) from $B$. falleni by the round cross section of the digitiform process and the more rounded apex of the gonostyli in lateral view; (3) from B. lambertoni by having an anal tube that is more strongly curved posteriorly in lateral view and more elongate in dorsal view; (4) from B. pionneaui by the more rounded apex of the basodorsal digitiform process of the gonostyli and the more strongly notched ventroapical margin of the anal tube under the anal opening in lateral view.

\section{Distribution}

See Fig. 48.

Belbina lambertoni Lallemand, 1922

Figs 7A-E, 24-25, 39, 49

Belbina lambertoni Lallemand, 1922: 62 (type in FSAG).

Belbina lambertoni var. minuta Lallemand, 1922: 62 (type in FSAG).

Belbina lambertoni - Lallemand 1959: 91, fig. 39a-d (lateral view of head, male genitalia). — Constant 2004b: 31 (listed).

Belbina lambertoni var. minuta - Lallemand 1959: 91 (synonymised with B. lambertoni Lallemand, 1922).

\section{Diagnostic characters}

(1) disc of hind wings red (Fig. 7A); (2) tegmina orange to red with 3 large black patches on costal cell and one at base of clavus (Fig. 7A); (3) cephalic process strongly curved dorsad (Fig. 7D); (4) largesized (more than $24 \mathrm{~mm}$ long); (5) head orange (Fig. 7C-E).

LT: $\hat{\partial}(\mathrm{n}=12) 27.8 \mathrm{~mm}(24.6-30.1) ;$ ㅇ $(\mathrm{n}=17) 34.5 \mathrm{~mm}(32.5-38.2)$. 


\section{Material examined}

Holotype

MADAGASCAR: + , [Manjakandriana, Madagascar] [Type] [Belbina lambertoni Lall, V. Lallemand det., 195] (FSAG).

\section{Paratypes}

MADAGASCAR: 5 $ぇ, 2$ $\uparrow$, [Manjakandriana, Madagascar] [Paratype] (FSAG; 1 q: MRAC); 1 , [Manjakandriana, Madagascar] [Type] [Belbina lambertoni Lall, V. Lallemand det., 1959] [NHRSHEMI 000000104] (NHRS); 1 \&, [Manjakandriana, Madagascar] [Paratype] [Musée du Congo] [Belbina

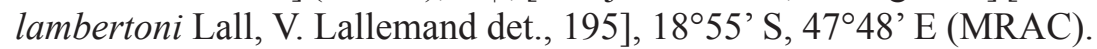

Note: Lallemand $(1922,1959)$ stated that the type and paratypes are in his collection. It seems, however, that he subsequently gave one paratype to NHRS and two to MRAC.

\section{Additional material}

MADAGASCAR: $2 \jmath^{\Uparrow} \widehat{\sigma}^{2}, 2$ 우우, near Tananarive, Lamberton, Tananarive (Antananarivo), $18^{\circ} 55^{\prime} \mathrm{S}$,

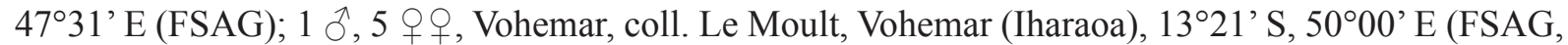

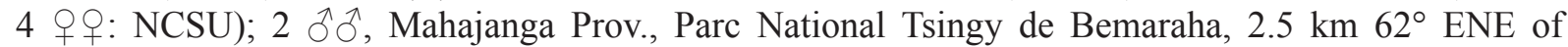
Bekopaka, Ankidrodroa River, 197'56” S, 4448'53” E, 100 m, 11-15 Nov. 2001, tropical dry forest

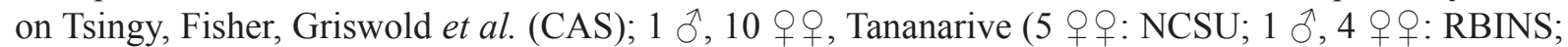

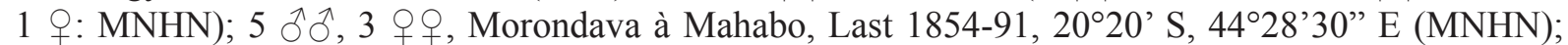
1 ․ Antalaha region, Dec. 1935, Vadon, $14^{\circ} 53^{\prime} \mathrm{S}, 50^{\circ} 17^{\prime} \mathrm{E}$ (MNHN); 3 우, Madagascar, coll. De Bergevin (MNHN); 1 \%, Vohemar, coll. de Bergevin (MNHN); 1 đ’, Ambatofitorano, Jul. 1978, 2049' S,

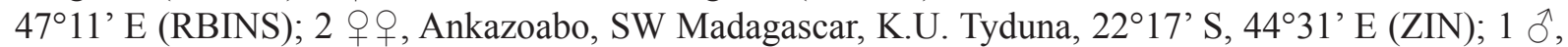

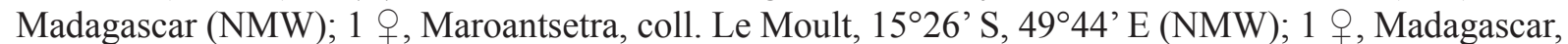

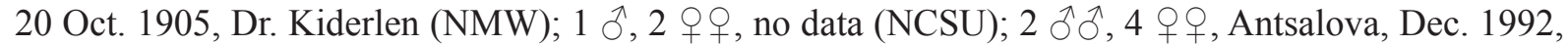

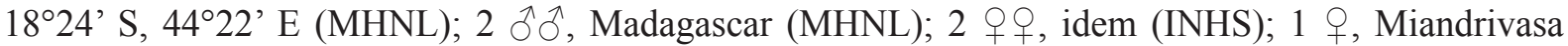

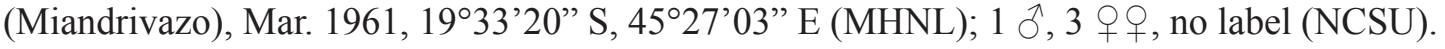

\section{Examined on photograph}

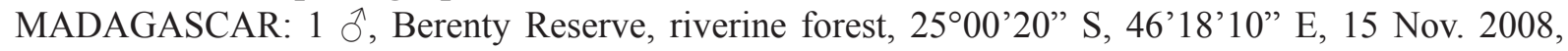
Jason Cryan (Fig. 39).

\section{Male genitalia}

Bright red (Figs 24-25); pygofer higher than long and with posterior margin bisinuate in lateral view (Fig. 24); anal tube slightly elongate, 1.1 times longer than broad at apex and with lateral margins slightly bisinuate, slightly concave on apical half in dorsal view (Fig. 25); posterior margin slightly notched in lateral view (Fig. 24), with hind margin of anal opening pointed posteriorly in lateral view (Fig. 24) and hiding lateral margin apically in dorsal view (Fig. 25); gonostyli elongate, 1.12 times longer than high (dorsal process included), surpassing anal tube and rounded at apex in lateral view (Fig. 24); ventral margin straight on basal 1/6, then slightly sinuate (Fig. 24); dorsal margin with basal, strong digitiform process projecting laterodorsally, strong hook laterally at middle of process projecting posteroventrally and posterior margin of process sinuate between apex and hook (Fig. 24); apex of digitiform process rounded and broad in lateral and dorsal view (Figs 24-25).

\section{Remarks}

Belbina lambertoni is a member of the falleni+ group, showing a strong basodorsal digitiform process on the gonostyli. It can be separated (1) from B. bloetei by the less concave ventral margin and more rounded apex of the gonostyli in lateral view; (2) from $B$. falleni by the round cross section of the digitiform process and the more rounded apex of the gonostyli in lateral view; (3) from B. laetitiae sp. nov. by the anal tube being less curved posteriorly in lateral view and less elongate in dorsal view; (4) 
from $B$. pionneaui by the more rounded apex of the basodorsal digitiform process of the gonostyli and the more strongly notched ventroapical margin of the anal tube under the anal opening in lateral view.

\section{Distribution}

See Fig. 49.

Belbina madagascariensis (Westwood, 1851) comb. nov.

Figs 8A-E, 26-27, 46

Aphana madagascariensis Westwood, 1851: 208 (neotype in MNHN).

Aphana madagascariensis - Walker 1852: 1134 (listed). — Stål 1866: 263 (listed). — Lallemand 1959: 85 (description, comments). - Constant 2004b: 31 (listed, comments).

Aphaenina madagascariensis - Metcalf 1947: 152 (catalogued).

\section{Diagnostic characters}

(1) disc of tegmina red or orange (Fig. 8A); (2) cephalic process elongate and narrow, projecting anterodorsad (Fig. 8D-E); (3) ground colour of tegmina brown (Fig. 8A); (4) large-sized (more than $26 \mathrm{~mm}$ long); (5) black-brown spots with white center on tegmina (Fig. 8A).

\section{Material examined}

\section{Neotype}

MADAGASCAR: +, neotype of Aphana madagascariensis Westwood, 1851, here designated, [Goudot Madagascar 1832] [Museum Paris] [Pterobaptes. Amyot.-vari-egata Spin. A. Fr. VIII. 225.-Senegal] [Neotype 9 Aphana madagascariensis Westwood, 1851 J. Constant des. 2013] [Belbina madagascariensis (Westwood, 1851) Det. Jérôme Constant 2013] (MNHN).

Note: A neotype is here designated in order to stabilise the nomenclature in the group, following rule 75.3 of the International Code of Zoological Nomenclature (ICZN 1999). The specimen chosen here is probably the one on which Westwood (1851) based his description. It was collected by Jules Prosper Goudot in 1832 and included in the collections of the MNHN in 1834 (Adeline Soulier-Perkins pers. comm.). Westwood (1851) stated that the specimen he examined was from the collections of the "Mus. Jardin des Plantes, Paris", the name of the MNHN at that time. No specimen labelled Aphana madagascariensis was found in the collections of the MNHN, but the specimen chosen here perfectly matches the original description. Lallemand (1959) assumed that the type was lost and stated that, according to the description, the species probably belonged to Belbina or Cornelia. As it is not totally certain that the specimen is the one on which the original description was based, I designate it here as a neotype rather than recognize it as the holotype.

\section{Additional material}

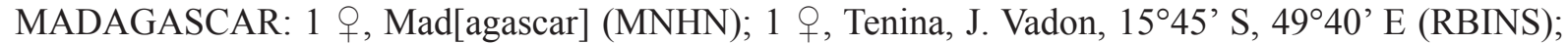

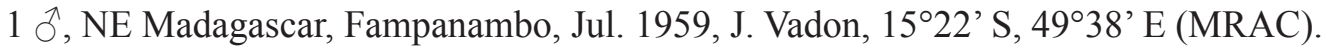

\section{Redescription}

LT: ô $(\mathrm{n}=1) 26.3 \mathrm{~mm}$; $q(\mathrm{n}=1) 28.3 \mathrm{~mm}$.

HeAD. Yellow-brown with 2 darker patches on disc of vertex (Fig. 8C-E); yellow-orange patch around insertion of antennae (Fig. 8D); vertex with hind margin slightly carinate and obsolete median carina on disc extending posterad beyond hind margin; sides of vertex strongly carinate, laminate above eye and extending anteriorly to apex of cephalic process; sides of vertex slightly bisinuate in lateral view (Fig. 8C-D); frons with 2 carinae extending ventrally on sides of process (Fig. 8E); cephalic process about 
3.2 times as long as diameter of eye, projecting anterodorsad, curved, elongate and narrow; apical half ventrally with median carina getting laminate near apex (Fig. 8D-E); transverse wrinkles dorsally at base of process (Fig. 8C); postclypeus with sides strongly carinate and slight median carina; anteclypeus with median carina (Fig. 8E); labium very long, reaching or surpassing apex of abdomen.

THORAX. Yellow-brown with slightly paler markings (Fig. 8C-E); pronotum with strong median carina (Fig. 8C); carina very slightly sinuate in lateral view (Fig. 8D) and with strongly impressed point on each side (Fig. 8C); hind margin elevated above level of mesonotum medially (Fig. 8D); peridiscal carina anteriorly (Fig. 8C); sides of prothorax with oblique carina; lateral lobe of pronotum rounded posteriorly (Fig. 8D-E); mesonotum with median carina stopped at scutellum; curved peridiscal carina; short oblique carina at base of scutellum; scutellum transversely wrinkled (Fig. 8C).

Tegmina (Fig. 8A). Brown with irregular black-brown, often confluent, small spots with pale yellowbrown center; center of spots covered with white waxy secretion in fresh specimens; no spots beyond nodal line of cross-veins except at apicosutural angle; apex of clavus with large black-brown marking followed by white patch along sutural margin; costal margin straight, slightly rounded after nodal line; apical margin oblique, straight in middle and with angles rounded; sutural margin sinuate.

HIND wINGs (Fig. 8A). Broad; disc largely bright red or orange; apex and sutural margin brown-black; 2-4 small, brown-black spots on disc; sutural margin bisinuate.

LegS (Fig. 8A). Elongate and slender; pro- and mesofemora brown with 3 narrow, sinuate and often incomplete pale yellow rings; pro- and mesotibiae brown with 2 pale yellow rings; metafemora brown with imprecise yellow ring; metatibiae and metatarsi yellow-brown, tibiae darker basally; metatibiae with 5 (sometimes 4) lateral and 7 apical spines; 8-9 spines apicoventrally on first metatarsomere.

AвDOMEN (Fig. 8A). Red dorsally, brown-black ventrally.

\section{Male genitalia}

Very finely granulose, dark brown, paler along sides of anal tube (Figs 26-27); pygofer higher than long and with posterior margin broadly rounded in lateral view (Fig. 26); anal tube slightly elongate, 1.31 times longer than broad at apex and with lateral margins sinuate in dorsal view (Fig. 27); posterior margin obliquely rounded and underside nearly straight in lateral view (Fig. 26); gonostyli elongate, 1.6 times longer than high, not surpassing anal tube and broadly rounded at apex in lateral view (Fig. 26); ventral margin slightly sinuate on basal $2 / 3$ (Fig. 26); dorsal margin obliquely directed dorsally on basal half, then straight after angle, pointed hook-like tooth at half of basal oblique part curved lateroventrally (Fig. 26); gonostyli nearly not visible from above (Fig. 27).

\section{Remarks}

Male genitalia without basodorsal process on gonostyli.

Belbina madagascarensis can be separated (1) from B. bergrothi by the less elongate gonostyli, without large pale marking ventrally and more broadly rounded apex, and less elongate anal tube; (2) from $B$. foliacea by having gonostyli more broadly rounded apically and without a strong angle above the mediodorsal tooth; (3) from B. nympha by having the margins of the anal tube not rounded laterally and the dorsal margin of the gonostyli nearly straight on the apical half; (4) from B. recurva by having the anal tube not produced into a semi-circular lateral plate.

\section{Distribution}

Fig. 46. 
Belbina nympha (Stål, 1866) comb. nov.

Figs 9A-E, 28-29, 50

Cornelia nympha Stål, 1866: 142 (type in NHRS).

Enchophora atomaria Brancsik, 1893: 253, pl. 11: figs 7, 7a (type in HNHM). syn. nov.

Cornelia nympha - Schmidt 1911: 242 (listed). - Jacobi 1917: 526 (listed). - Metcalf 1947: 122 (catalogued). - Lallemand 1959: 87, fig. 33 (key, description, lateral view of head). — Constant 2004b: 31, fig. 4 (listed, habitus).

Enchophora atomaria - Metcalf 1947: 114 (catalogued).

Cornelia atomaria - Lallemand 1959: 88, fig. 35 (key, description, lateral view of head). - Constant 2004b: 31 (listed).

\section{Diagnostic characters}

(1) disc of hind wings red or orange (Fig. 9A); (2) ground colour of tegmina brown (Fig. 9A); (3) smallsized (less than $22 \mathrm{~mm}$ long); (4) cephalic process directed anterodorsad (Fig. 9D); (5) abdomen with 2 rows of black spots (Fig. 9A).

LT: Љ $(\mathrm{n}=3) 18.9 \mathrm{~mm}(18.0-19.8)$; ๆ $(\mathrm{n}=3) 20.6 \mathrm{~mm}(19.6-21.9)$.

\section{Material examined}

Type material

MADAGASCAR: Holotype of Cornelia nympha, ㅇ, [Madag.] [Stål] [Cornelia Stål] [Typus] [NHRSHEMI 000000106] (NHRS).

MADAGASCAR: Holotype of Enchophora atomaria, ô, [Madagascar, Nossi-Bè] [atomaria Brancs., Coll. Brancsik] [Holotypus, Enchophora atomaria n.sp., Brancsik, 1893], 13²0’ S, 48 $15^{\prime}$ E (HNHM).

\section{Additional material}

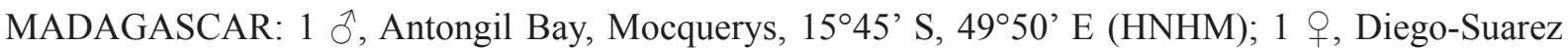
Prov., forest area $7 \mathrm{~km} \mathrm{~N}$ of Joffreville, $12^{\circ} 20^{\prime} \mathrm{S}, 4^{\circ} 15^{\prime} \mathrm{E}, 360 \mathrm{~m}, 22-26 \mathrm{Jan}$. 2001, Malaise trap, Irwin, Schlinger \& Harin'Hala (CAS); 1 §, Nosy-Be (BMNH); 1 + , Diego-Suarez, coll. De Bergevin

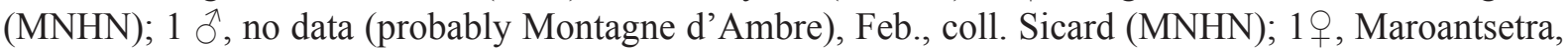
$15^{\circ} 26^{\prime}$ S, 4944' E (FSAG); 10, Nosy Komba, flanc, May 1956, A.R., Institut Scientifique Madagascar, Nosy Komba (Nosy Koba), 12¹2’ S, 49¹6’ E (FSAG); 1 , Nosibé (FSAG); 1 q, Madagascar (MNPC).

\section{Male genitalia}

Very finely granulose, dark brown, with gonostyli slightly paler dorsally and ventrally (Figs 29-30); pygofer higher than long and with posterior margin broadly sinuate in lateral view (Fig. 29); anal tube elongate, 1.43 times longer than broad at apex and with lateral margins diverging on basal half, then broadly rounded in dorsal view (Fig. 30); curved ventrally and with posterior margin acutely rounded apically in lateral view (Fig. 29); gonostyli elongate, 1.63 times longer than high, not surpassing anal tube and broadly rounded at apex in lateral view (Fig. 29); all margins broadly rounded except dorsal margin obliquely straight on basal half (Fig. 29); lateral hook-shaped tooth at base of dorsal margin curved lateroventrally (Fig. 29); gonostyli nearly not visible from above (Fig. 30).

\section{Remarks}

Male genitalia without basodorsal process on gonostyli. 
Belbina nympha can be separated (1) from B. bergrothi by the less elongate gonostyli, without large pale marking ventrally and more broadly rounded apex, and the less elongate anal tube; (2) from B. foliacea by having gonostyli more broadly rounded apically and without a strong angle above the mediodorsal tooth; (3) from B. madagascariensis by having the margins of the anal tube rounded laterally and the dorsal margin of the gonostyli broadly rounded on the apical half; (4) from B. recurva by not having the anal tube produced into a semi-circular lateral plate.

\section{Distribution}

See Fig. 50.

Belbina pionneaui Lallemand, 1922

Figs 10A-E, 30-31, 51

Belbina pionneaui Lallemand, 1922: 63 (type in FSAG).

Belbina pionneaui - Metcalf 1947: 123 (catalogued). — Lallemand 1959: 93, fig. 42 (key, description, lateral view of head). — Constant 2004b: 31 (listed).

\section{Diagnostic characters}

(1) disc of hind wings red (Fig. 10A); (2) tegmina dark red with membrane pale brown, numerous black-brown spots (Fig. 10A); (3) cephalic process broad, strongly curved dorsad (Fig. 10D-E); (4) large-sized (more than $25 \mathrm{~mm}$ long).

LT: ^̊ ( $\mathrm{n}=3) 25.6 \mathrm{~mm}(25.1-26.0)$; 우 $(\mathrm{n}=13) 30.6 \mathrm{~mm}(25.8-32.9)$.

\section{Material examined}

\section{Holotype}

MADAGASCAR: + , [Type] [Manjakandriana, Madagascar] [Belbina pionneaui Lallem.] (FSAG).

\section{Paratypes}

MADAGASCAR: $2 \AA \widehat{\jmath}, 6$ 우, [Manjakandriana, Madagascar] [Para-type] (FSAG); 1 , [Manjakandriana, Madagascar] [Para-type] [Belbina pionneaui Lall, V. Lallemand det., 1959] (NHRS); 1 , [Manjakandriana, Madagascar] [Para-type] [Belbina pionneaui Lallemand, V. Lallemand det., 1956], $18^{\circ} 55^{\prime} \mathrm{S}, 47^{\circ} 48^{\prime} \mathrm{E}$ (NHRS).

Note: Lallemand $(1922,1959)$ stated that the type and paratypes are in his collection. It seems, however, that he subsequently gave one of the paratypes to NHRS.

\section{Additional material}

MADAGASCAR: $1+$, Madagascar (RBINS); $2+q$, Tananarive, Lamberton, Tananarive (Antananarivo), $18^{\circ} 55^{\prime} \mathrm{S}, 47^{\circ} 31^{\prime} \mathrm{E}$ (RBINS); 1 今, 1 ㅇ, [“Ambatol...” (unreadable)], Lamberton (RBINS); 1 q,

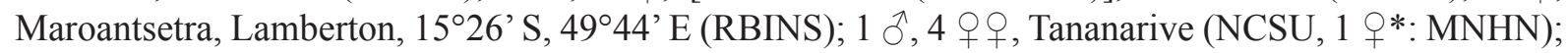
$2 \widehat{\partial}, 1$, no data (NCSU). - The specimen marked with * bears a label [Belbina pionneaui, cotype, Lallemand]. This specimen is not recognized as a paratype, as Lallemand (1959) stated that all type specimens were from Manjakandriana.

1 ô mislabeled "Soekaboemi, Java" has also been examined (INHS).

\section{Examined on photographs}

MADAGASCAR: 4 specimens, Tananarive, Lamberton (RMNH); 2 specimens, Maroantsetra, Lamberton (RMNH). 


\title{
Male genitalia
}

Dark red (Figs 30-31); pygofer higher than long and with posterior margin straight, slightly rounded on dorsal $1 / 4$ in lateral view (Fig. 30); anal tube slightly elongate, 1.28 times longer than broad at apex and with lateral margins bisinuate in dorsal view (Fig. 31); posterior margin broadly rounded in lateral view (Fig. 30) with hind margin of anal opening slightly projecting posteriorly (Fig. 30) and hiding lateral margin apically in dorsal view (Fig. 31); gonostyli elongate, 1.35 times longer than high (dorsal process included), strongly surpassing anal tube and rounded at apex in lateral view (Fig. 30); ventral margin straight on basal 1/5, then sinuate (Fig. 30); dorsal margin with basal digitiform process slightly curved posteriorly and projecting laterodorsally, strong hook laterally at middle of process projecting ventrally (Figs 30-31); digitiform process narrowing from base to apex and acutely rounded apically (Figs 30-31).

\section{Remarks}

Belbina pionneaui is a member of the falleni+ group, showing a strong basodorsal digitiform process on the gonostyli. It can be separated from all species of the group by having the basodorsal digitiform process of the gonostyli narrowing from the base to the apex and the apical margin of the anal tube not notched under the anal opening in lateral view.

\section{Distribution}

See Fig. 51.

Belbina recurva Lallemand, 1950

Figs 11A-E, 32-33, 40-42, 52

Belbina recurva Lallemand, 1950: 84 (type in FSAG).

Belbina recurva - Lallemand 1959: 90, fig. 37a-c (key, description, lateral view of head, male genitalia). —Constant 2004b: 31, fig. 3 (listed, habitus).

\section{Diagnostic characters}

(1) disc of hind wings red (Fig. 11A); (2) ground colour of tegmina variegated brown (Fig. 11A);

(3) veins of tegmina elevated (Fig. 11A); (4) large-sized (more than $26 \mathrm{~mm}$ long); (5) cephalic process very strongly curved and projecting posterodorsad (Fig. 11D-E); (6) abdomen with 2 rows of black spots dorsally (Fig. 11A).

LT: $\widehat{o}(\mathrm{n}=4) 27.3 \mathrm{~mm}(25.6-28.4) ;$; $(\mathrm{n}=2) 29.8 \mathrm{~mm}(29.8-29.9)$.

\section{Material examined}

\section{Holotype}

MADAGASCAR: ${ }^{\lambda}$, [Maroantsetra, Madagascar, Lamberton] [Type] [Belbina recurva Lallem., V. Lallemand det.:], $15^{\circ} 26^{\prime}$ S, 4944' E (FSAG).

\author{
Paratype \\ MADAGASCAR: 1 ๙ , [Maroantsetra, Madagascar, Lamberton] [Paratype] (FSAG).
}

\section{Additional material}

MADAGASCAR: 1 + , E Madagascar, Sambava district, Marojejy, Ambinanitelo, 500 m, Dec. 1958, Raharizonina, $15^{\circ} 21^{\prime}$ S, 49 $35^{\prime}$ E (RBINS); 1 ð’, Fianarantsoa, Ranomafana National Park, Talatakely, trail FF, 915-1000 m, 4-20 Nov. 1998, Lee \& Ribardo, 21ํ1' S, 47²7’ E (CAS); 1 q, E Madagascar, 
Ambodivoangy, Jan. 1960, J. Vadon, 15¹7'50” S, 49³6'47” E (MRAC); Antsianaka forest, 1964,

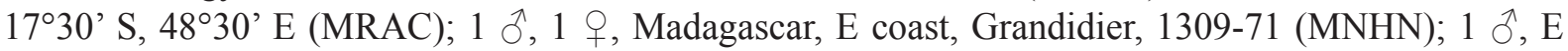
Madagascar, Mananara district, N Antanambe, Vadon \& Peyrieras, $16^{\circ} 26^{\prime} \mathrm{S}, 49^{\circ} 51^{\prime}$ E (MNHN); 1 ○े, E Madagascar, massif du Marojejy (rés. nat. intégr. 12), Ambatomitatao, 400 m, Jan. 1973, A. Peyrieras,

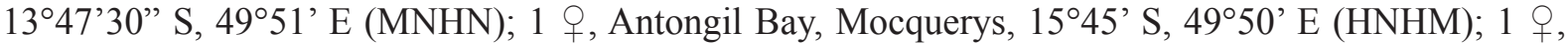

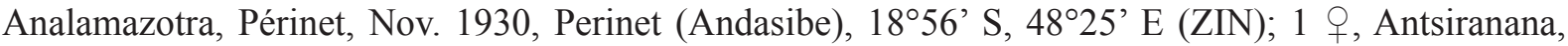
Parc National de Marojejy, Manantenina River, $28.0 \mathrm{~km} 38^{\circ} \mathrm{NE}$ of Andapa, $8.2 \mathrm{~km} 333^{\circ} \mathrm{NNW}$ of Manantenina, $14^{\circ} 26^{\prime} 12^{\prime}$ S, 49 46’30" E, 450 m, Malaise trap in rainforest, 12-25 Nov. 2003, B.L.

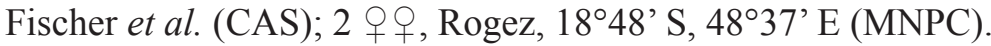

\section{Examined on photographs}

MADAGASCAR: 1 specimen, Masoala Peninsula, 30 May 2009, Dante Fenolio (Fig. 42), 15³0'48" S, 5007'20” E; 1 specimen, Anajanaharibe Sud, 2 May 2010, Becky Rowe (Fig. 41), 1446' S, 49 $26^{\circ}$ ' E; 1 specimen, Marojejy, near Cascade Humbert, 22 Nov. 2005 at 20:41, David C. Lees (Fig. 40), 14²6’ S, $49^{\circ} 42^{\prime} \mathrm{E}$.

\section{Male genitalia}

Black-brown with gonostyli slightly paler (Figs 32-33); pygofer higher than long and with posterior margin nearly straight in lateral view (Fig. 32); anal tube slightly transverse, 0.93 times as long as broad and with margins strongly projecting laterally on basal $2 / 3$ into semi-circular lamina in dorsal view, apical $1 / 3$ with lateral margins diverging towards apex (Fig. 33); apical margin acutely rounded in lateral view (Fig. 32); strong hump dorsally near base (Fig. 32); gonostyli elongate, 1.93 times longer than high, reaching apex of anal tube (Fig. 32); ventral margin broadly rounded to apex and dorsal margin strongly sinuate and with ante-apical notch in lateral view (Fig. 32); dorsal margin with strong, hook-shaped tooth at midlength pointing anteroventrally (Fig. 32); dorsal margin projecting laterally, semi-circular in dorsal view, with basal lobe and slightly folded internally near notch (Fig. 33).

\section{Remarks}

Male genitalia without basodorsal process on gonostyli.

Belbina recurva can be separated from all other species by having the anal tube produced into a semicircular lateral plate.

\section{Distribution}

See Fig. 52.

Belbina servillei (Spinola, 1839)

Figs 12A-E, 34-35, 53

Enchophora servillei Spinola, 1839: 227, pl. 2, fig. 3a-c (neotype in HMNH).

Enchophora servillei - Amyot \& Serville 1843: 496 (listed). — White 1846: 331 (comparative note). Walker 1851: 271 (catalogued). — Dohrn 1859: 57 (listed).

Phrictus servillei - Schaum 1850: 65 (listed).

Belbina servillei - Stål 1863a: 233 (description). — Stål 1866: 144 (key, description). — Jacobi 1917: 527 (listed). - Metcalf 1947: 123 (catalogued). — Constant 2004b: 31 (listed, comments on type).

non Belbina servillei - Lallemand 1959: 88, fig. 36a-c (key, description, lateral view of head, male genitalia) - [Misidentification of Belbina laetitiae sp. nov.] 


\section{Diagnostic characters}

(1) disc of hind wings turquoise (Fig. 12A); (2) head, pro- and mesonotum red (Fig. 12C-E); (3) ground colour of tegmina bluish-green (Fig. 12A); (4) cephalic process strongly curved, projecting dorsad (Fig. 12D).

LT: Љ̂ $(\mathrm{n}=1) 20.4 \mathrm{~mm}$; 우 $(\mathrm{n}=13) 23.3 \mathrm{~mm}(21.7-24.8)$.

\section{Material examined}

\section{Neotype}

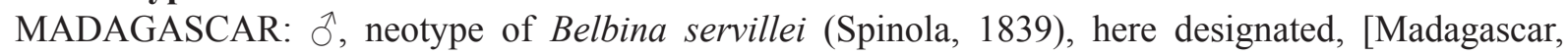

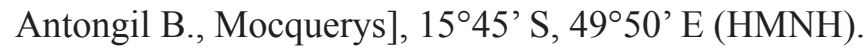

A neotype is designated here in order to ensure stability in the nomenclature of the group, following rule 75.3 of the International Code of Zoological Nomenclature (ICZN 1999). The origin of the specimen described by Spinola (1839) is unknown and Stål (1866) was the first to give a location for the species (Madagascar). Lallemand (1959) designated a lectotype in his collection (FSAG) that is invalid according to nomenclatural rules. Furthermore, the only labelled specimen of this species, [Belbina servillei Sign., V. Lallemand det., 1963], in Lallemand's collection is in fact a specimen of Belbina laetitiae sp. nov., as demonstrated by the genitalia illustrated in Lallemand (1959). In order to avoid further nomenclatural confusion, a neotype is designated which perfectly matches the illustrations given by Spinola (1839) and which is deposited in a public collection (HMNH). I chose a male with genitalia in good condition to facilitate further work on the species.

\section{Additional material}

MADAGASCAR: $1 \hat{\jmath}, 2$ qq+, no data (MNHN); 1 , near Tamatave, A. Raffray, 1884, Tamatave

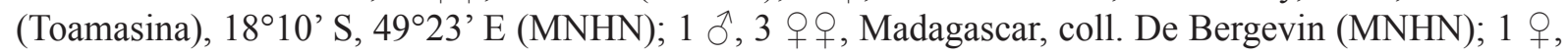

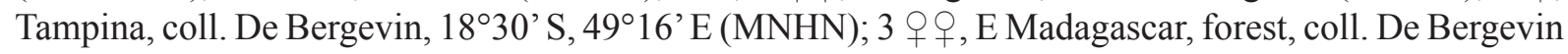
(MNHN); 1 + , Diego-Suarez, Ch. Alluaud, 1893, Diego Suarez (Ampanolahamirafy), 12 ${ }^{\circ} 16^{\prime}$ S, $49^{\circ} 17^{\prime}$

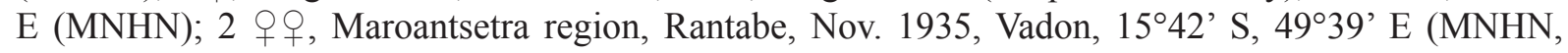

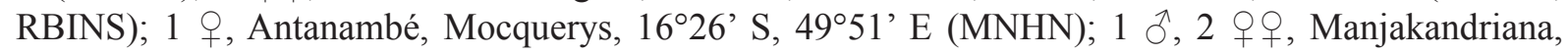

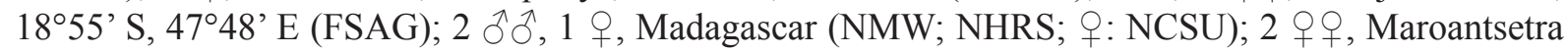
(NCSU).

1 đ̊ mislabelled "S. America, Coll. Signoret" has also been examined (NMW).

\section{Male genitalia}

Brown (Figs 34-35); pygofer higher than long and with posterior margin concave in middle in lateral view (Fig. 34); anal tube as long as wide at apex and with lateral margins roundly produced in middle in dorsal view (Fig. 35); posterior margin of anal tube acutely rounded posteriorly in lateral view (Fig. 34) and hiding lateral margin apically in dorsal view (Fig. 35); gonostyli elongate, 1.33 times longer than high (including dorsal process, 1.88 times without process), strongly surpassing apex of anal tube and rounded at apex in lateral view (Fig. 34); ventral margin rounded on basal 1/5, then nearly straight (Fig. 34); dorsal margin with basal, strong, laminate process projecting dorsally, strong hook laterally at middle of process projecting ventrally; dorsal half of process slightly excavate and narrowly rounded dorsally, dorsal margin of gonostyli bisinuate after process (Fig. 34); gonostyli minutely rugulose on ventral half (Fig. 34).

\section{Remarks}

Belbina servillei can be separated (1) from all species of the B. falleni+ group by the brown colour of the genitalia, the laminate basodorsal digitiform process on the gonostyli and having the gonostyli 

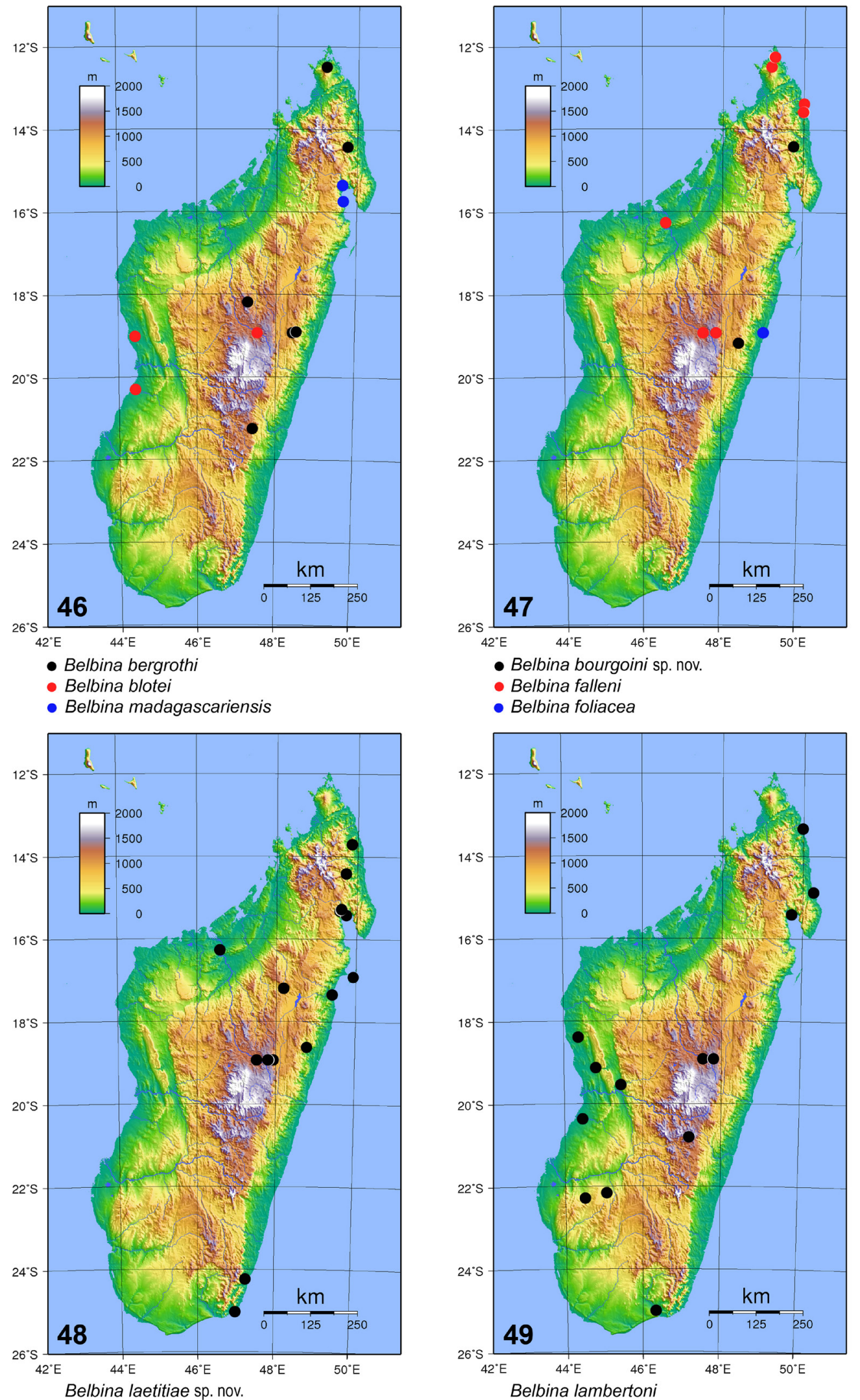

Figs 46-49. Distribution maps. - 46. Belbina bergrothi, B. bloetei and B. madagascariensis. 47. B. bourgoini sp. nov., B. falleni and B. foliacea. 48. B. laetitiae sp. nov. 49. B. lambertoni. 

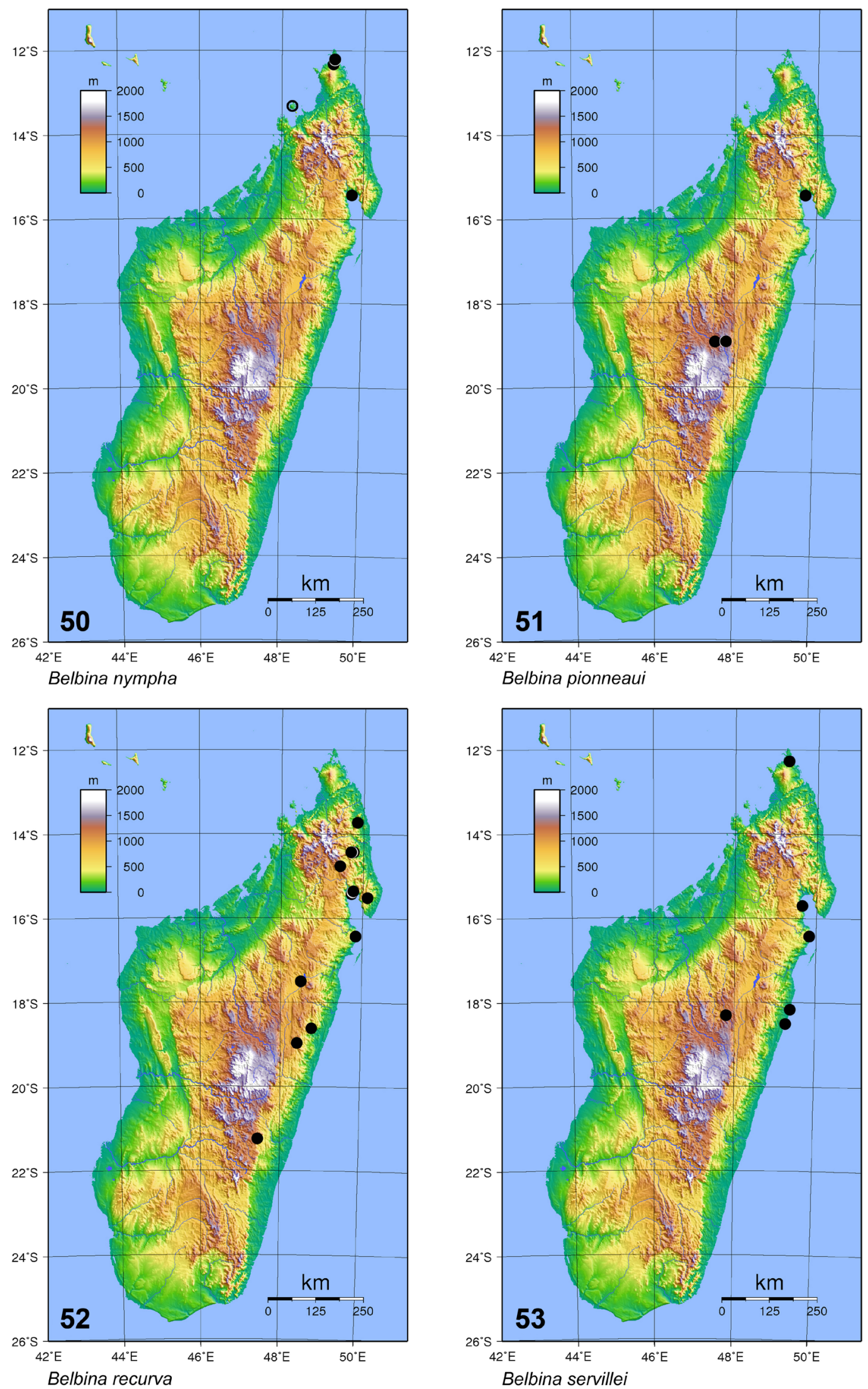

Figs 50-53. Distribution maps. - 50. Belbina nympha. 51. B. pionneaui. 52. B. recurva. 53. B. servillei. 
rounded at the apex, with the dorsal margin sinuate after the process; (2) from B. bergrothi, B. foliacea, B. madagascariensis and $B$. nympha by the basodorsal laminate process on the gonostyli; (3) from $B$. bourgoini sp. nov. by the laminate basodorsal process of the gonostyli.

\section{Distribution}

See Fig. 53.

\section{Discussion}

The genus Belbina contains most of the species of Fulgoridae recorded from Madagascar, 12 out of 17 (Constant 2004b), with the 5 other species belonging to the genera Antsalovasia Constant, 2004, Radamana Distant, 1906 and Zanna Kirkaldy, 1902. Belbina, Antsalovasia and Radamana are endemic to Madagascar while Zanna is also found in Afrotropical and Oriental regions.

Although the species of Belbina often have a wide distribution range (see maps on Figs 46-53), they are not regularly collected, probably due to their cryptic colour when sitting on tree trunks (see Figs 36, 38, 42). More field work should be conducted to document their life-history and to make observations on the host plants and the biology of these insects. Although they are actively searched by collectors, the feeding habits, larval stages and eggs remain unknown for all species.

\section{Acknowledgements}

I thank here all the curators listed above for the loan of the material. I also thank Mr Nicolas Cliquennois (Madagascar), Dr Rhett A. Butler (USA), Dr David C. Lees (France), Dr Danté B. Fenolio (USA), Dr Jason Cryan (USA), Mr Paul Bertner (Canada) and Mrs Becky Rowe (UK) for the permission to use their photographs, Dr Patrick Grootaert (RBINS) and Mr Pol Limbourg (RBINS) for their support and comments, Mrs Yvonne van Nierop (RMNH) and Mrs Gunvi Lindberg (NHRS) for sending photographs of several specimens, and Mr Yves Laurent and Mrs Isabelle Bachy, with the kind permission of Dr Maurice Leponce (RBINS), for taking and processing the photographs of the genitalia.

This study has also benefited from funds from the European Union for a visit to the collections of the MNHN (COLPARSYST project) and NHRS (Synthesys project), and from MHNL for a visit to its collections so kindly arranged by Messrs Cédric Audibert, Joël Clary and Harold Labrique.

Drs Julie Urban, Jason Cryan and Charles Bartlett are warmly thanked for sharing preliminary results of their molecular studies on Fulgoridae.

\section{References}

Amyot C.J.B. \& Serville J. 1843. Histoire naturelle des hémiptères. Hemiptera Linn. - Latr. Histoire Naturelle des Insectes 8: 1-676. http://dx.doi.org/10.5962/bhl.title.8471

Bourgoin T. 2014. FLOW (Fulgoromorpha Lists on The Web): a world knowledge base dedicated to Fulgoromorpha. V.8, updated [14 Apr. 2014]. http://hemiptera-databases.org/flow/

Brancsik K. 1893. Beiträge zur Kenntniss Nossibé's und dessen Fauna nach Sendungen und Mittheilungen des Herrn P. Frey. Jahresheft des Naturwissenschaftlichen Vereines des Trencséner Comitates 15-16: $135-159$.

Constant J. 2004a. Révision des Eurybrachidae (I). Le genre Amychodes Karsch, 1895 (Homoptera: Fulgoromorpha: Eurybrachidae). Bulletin de l'Institut royal des Sciences naturelles de Belgique 74: $11-28$. 
Constant J. 2004b. Fulgoridae of Madagascar: description of a new species representing a new genus, key to the genera and list of the species (Homoptera: Fulgoromorpha: Fulgoridae). Bulletin de l'Institut royal des Sciences naturelles de Belgique 74: 29-34.

Constant J. 2010. The lanternfly genus Penthicodes: key to the species and review of the "Ereosoma group" with two new species and one new subspecies (Hemiptera: Fulgoromorpha: Fulgoridae). Zootaxa 2523: 1-26. http://www.mapress.com/zootaxa/2010/1/zt02523p026.pdf

Dohrn F. 1859. Catalogus Hemipterorum. Herrcke \& Lebeling, Entomologischer Verein zu Stettin. http://dx.doi.org/10.5962/bhl.title.8515

Gerstaecker C.E.A. 1873. Baron Carl Claus von der Decken's Reisen in Ost-Afrika in den Jahren 1859-1865. Vol. 3, issue 2. C.F. Winter'sche Verlagshandlung, Leipzig \& Heidelberg. http://dx.doi. org/10.5962/bhl.title.33914

ICZN. 1999. International Code of Zoological Nomenclature. Fourth Edition. The International Trust for Zoological Nomenclature, London, U.K. http://iczn.org/iczn/index.jsp

Jacobi A. 1917. Die Zikadenfauna Madagascars und der Comoren. Reise in Ostafrika in den Jahren 1903-1905 mit Mitteln der Hermann und Elise geb. Heckman Wentzel-Stiftung ausgefürt von Professor Dr. Alfred Voeltzkow. Wissenschaftliche Ergebnisse. Systematische Arbeiten 3 (5): 519-552. http://www. biodiversitylibrary.org/item/131294\#page/329/mode/1up

Karsch F. 1890. Afrikanische Fulgoriden. Berliner Entomologische Zeitschrift 35 (1): 57-70. http:// biodiversitylibrary.org/page/25049326

Karsch F. 1893. Beiträge zur Fauna des Togolandes nach den Sammlungen der Herren Hauptmann E. Kling und Dr. R. Büttner. Mitteilungen von Forschungsreisen und Gelehrten aus den Deutschen Schutzgebieten 4 (3): 219-229.

Lallemand V. 1922. Homoptères nouveaux. Bulletin du Muséum National d'Histoire Naturelle 28: 6268. http://biodiversitylibrary.org/page/34159669

Lallemand V. 1950. Contribution à l'étude des homoptères de Madagascar. Mémoires de l'Institut Scientifique de Madagascar 4A: 83-95.

Lallemand V. 1959. Révision des espèces africaines de la famille Fulgoridae (super-famille Fulgoroides - sous-ordre des homoptères). Publicaçoes Culturais da Companhia de Diamantes de Angola 41: 37124.

Latreille P.A. 1807. Sectio secunda. Familia quarta. Cicadariae. Cicadaires. Genera Crustaceorum et Insectorum secundum ordinem naturalem in familias disposita, iconibus exemplisque plurimis explicata 3: 1-258. http://dx.doi.org/10.5962/bhl.title.11558

Melichar L. 1908. Nové rody a druhy Homopter z vychodni Afriky. Casopis Ceské Spolecnosti Entomologické, Praha 5: 1-15. http://biodiversitylibrary.org/page/12738193

Metcalf Z.P. 1947. General Catalogue of the Homoptera. Fascicle IV. Fulgoroidea. Part 9. Fulgoridae. North Carolina State College, Raleigh.

Nast J. 1977. Homopterological notes XII-XX. Annales Zoologici 34 (2): 27-37.

Schaum H. 1850. Fulgorellae. Allgemeine Encyklopädie der Wissenschaften und Kunste in alphabetischen Folge von Genannten Schriftstellern bearbeitet und herausgegeben von I.S. Ersch und I.G. Gruber mit Kupfern und Charten. Erster Section A-G, 51: 58-73.

Schmidt E. 1911. Beitrag zur Kenntnis der Homopteren. (Neue Gattungen und Arten). Stettiner Entomologische Zeitung 72: 238-307. http://biodiversitylibrary.org/page/9013241 
Schumacher F. 1918. Die Fulgoriden-Gattung Druentia Stål (Pyrgoteles Gerst.). Deutsche Entomologische Zeitschrift 1918 (4): 110-112. http://biodiversitylibrary.org/page/33047045

Spinola M. 1839. Essai sur les Fulgorelles, sous-tribu de la tribu des Cicadaires, ordre des Rhyngotes. Annales de la Société Entomologique de France 8: 133-337. http://biodiversitylibrary.org/page/33710046

Stål C. 1863a. Beitrag zur Kenntniss der Fulgoriden. Stettiner Entomologische Zeitung 24: 230-251. http://biodiversitylibrary.org/page/35950043

Stål C. 1863b. Hemipterorum exoticorum generum et specierum nonnullarum novarum descriptiones. Transactions of the Entomological Society of London, Series 3, 1: 571-603. http://biodiversitylibrary. org/page/32121525

Stål C. 1866. Hemiptera Homoptera Latr. Hemiptera Africana 4: 1-276. http://biodiversitylibrary.org/ page/ 8695280

Urban J. \& Cryan J. 2009. Entomologically famous, evolutionarily unexplored: the first phylogeny of the lanternfly family Fulgoridae (Insecta: Hemiptera: Fulgoroidea). Molecular Phylogenetics and Evolution 50: 471-484. http://dx.doi.org/10.1016/j.ympev.2008.12.004

Walker F. 1851. List of the Species of Homopterous Insects in the Collection of the British Museum 2: 261-636. http://dx.doi.org/10.5962/bhl.title.9063

Walker F. 1852. Supplement. List of the Species of Homopterous Insects in the Collection of the British Museum 4: 1119-1188. http://dx.doi.org/10.5962/bhl.title.9063

Westwood J.O. 1851. Description of some new species of exotic homopterous insects. Annals and Magazine of Natural History, Series 2, 7: 207-210. http://biodiversitylibrary.org/page/13787797

White A. 1846. Description of some apparently new species of homopterous insects in the collection of the British Museum. Annals and Magazine of Natural History 17: 330-333. http://biodiversitylibrary. org/page/22161952

Manuscript received: 7 July 2014

Manuscript accepted: 29 August 2014

Published on: 14 November 2014

Topic editor: Koen Martens

Desk editor: Danny Eibye-Jacobsen

Printed versions of all papers are also deposited in the libraries of the institutes that are members of the EJT consortium: Muséum National d'Histoire Naturelle, Paris, France; National Botanic Garden of Belgium, Meise, Belgium; Royal Museum for Central Africa, Tervuren, Belgium; National History Museum, London, United Kingdom; Royal Belgian Institute of Natural Sciences, Brussels, Belgium; Natural History Museum of Denmark, Copenhagen, Denmark. 